\title{
Macroecology of Calanus finmarchicus and C. helgolandicus in the North Atlantic Ocean and adjacent seas
}

\author{
Pierre Helaouët ${ }^{1,2, *}$, Grégory Beaugrand ${ }^{1}$ \\ ${ }^{1}$ Centre National de la Recherche Scientifique (CNRS), FRE 2816 ELICO, Station Marine, BP 80, 62930 Wimereux, France \\ ${ }^{2}$ Present address: Sir Alister Hardy Foundation for Ocean Science, The Laboratory, Citadel Hill, Plymouth PL1 2PB, UK
}

\begin{abstract}
Global climate change is expected to modify the spatial distribution of marine organisms. However, projections of future changes should be based on robust information on the ecological niche of species. This paper presents a macroecological study of the environmental tolerance and ecological niche (sensu Hutchinson 1957, i.e. the field of tolerance of a species to the principal factors of its environment) of Calanus finmarchicus and C. helgolandicus in the North Atlantic Ocean and adjacent seas. Biological data were collected by the Continuous Plankton Recorder (CPR) Survey, which samples plankton in the North Atlantic and adjacent seas at a standard depth of $7 \mathrm{~m}$. Eleven parameters were chosen including bathymetry, temperature, salinity, nutrients, mixed-layer depth and an index of turbulence compiled from wind data and chlorophyll a concentrations (used herein as an index of available food). The environmental window and the optimum level were determined for both species and for each abiotic factor and chlorophyll concentration. The most important parameters that influenced abundance and spatial distribution were temperature and its correlates such as oxygen and nutrients. Bathymetry and other water-column-related parameters also played an important role. The ecological niche of $C$. finmarchicus was larger than that of $C$. helgolandicus and both niches were significantly separated. Our results have important implications in the context of global climate change. As temperature (and to some extent stratification) is predicted to continue to rise in the North Atlantic sector, changes in the spatial distribution of these 2 Calanus species can be expected. Application of this approach to the 1980s North Sea regime shift provides evidence that changes in sea temperature alone could have triggered the substantial and rapid changes identified in the dynamic regimes of these ecosystems. C. finmarchicus appears to be a good indicator of the Atlantic Polar Biome (mainly the Atlantic Subarctic and Arctic provinces) while C. helgolandicus is an indicator of more temperate waters (Atlantic Westerly Winds Biome) in regions characterised by more pronounced spatial changes in bathymetry.
\end{abstract}

KEY WORDS: Macroecological approach $\cdot$ Hutchinson ecological niche $\cdot$ Biogeography $\cdot$ Calanus finmarchicus · Calanus helgolandicus · North Atlantic Ocean · Continuous Plankton Recorder

\section{INTRODUCTION}

Understanding the consequences of variability in climate on pelagic ecosystems requires a clear identification of the factors driving variability in the abundance of each species and the parameters or processes that control their geographical distribution. Biogeographical studies are essential and provide a baseline for evaluation of the impact of climate on ecosystems (Longhurst 1998, Beaugrand 2003).

The high nutrient supply in the temperate and subpolar part of the North Atlantic Ocean results in high planktonic production (Ducklow \& Harris 1993, Longhurst 1998). This region is influenced by the North Atlantic Current which transfers energy and heat from the SW oceanic region of Newfoundland to the NE 
part of the North Atlantic Ocean (Krauss 1986). This current also has a profound impact on plankton diversity (Beaugrand et al. 2001). The North Atlantic Ocean is divided into 3 biomes: the Atlantic Polar Biome, the Atlantic Westerly Winds Biome and the Atlantic Coastal Biome, each divided into a number of provinces (present Fig. 1; Longhurst 1998). Their ecological characteristics have been recently reviewed by Longhurst (1998) and some complementary descriptions have been added by Beaugrand et al. $(2001,2002)$ for the northern part of the North Atlantic Ocean and its adjacent seas.

Copepods constitute a key trophic group, with a central role in the trophodynamics of pelagic ecosystems. These plankton organisms transfer energy from the phytoplankton to higher trophic levels (Mauchline 1998) and are often important in the diet of at least 1 developmental stage of economically important fish species such as cod, herring or mackerel (Sundby 2000, Orlova et al. 2005, Skreslet et al. 2005). Copepods represent a high proportion of the carbon biomass in the mesozooplankton, generally increasing with increasing latitude (e.g. $33 \%$ for the Atlantic Trade Wind Biome, $53 \%$ for the Atlantic Westerly Winds Biome and $69 \%$ for the Arctic Ocean, Longhurst 1998). Members of the genus Calanus are amongst the largest copepods and can comprise as much as $90 \%$ of the dry weight of the mesozooplankton in regions such as the North Sea and the Celtic Sea (Bonnet et al. 2005 and references therein). The congeneric calanoid copepod species $C$. finmarchicus and C. helgolandicus

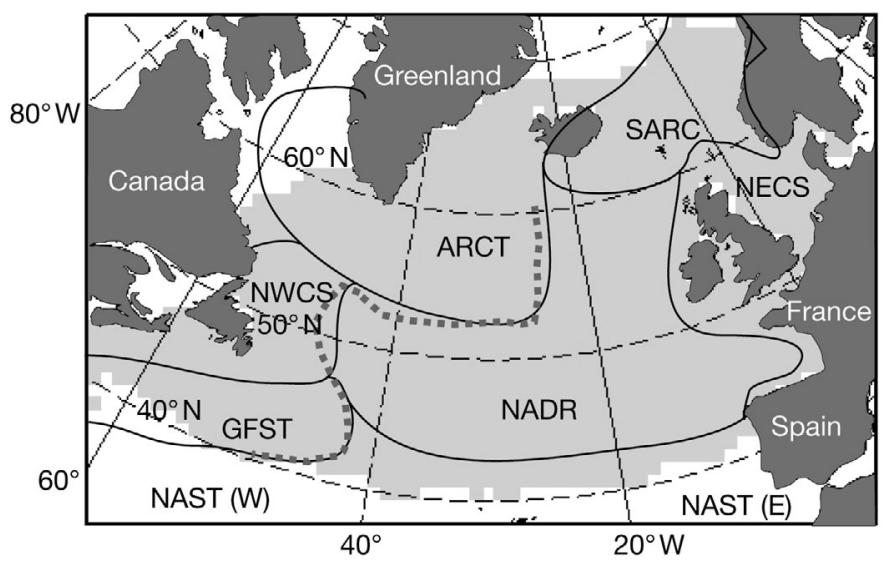

Fig. 1. Main area (light grey) sampled by the Continuous Plankton Recorder survey from 1960 to 2002, and provinces (Longhurst 1998). Atlantic Polar Biome-SARC: Atlantic subarctic province; ARCT: Atlantic arctic province. Atlantic Westerly Winds Biome-NADR: North Atlantic Drift province; NAST: North Atlantic subtropical gyral province (W and E: western and eastern parts, respectively); GFST: Gulf Stream province. Atlantic Coastal Biome - NECS: Northeast Atlantic shelves province; NWCS: Northwest Atlantic shelves province. Thick dotted line: Oceanic Polar Front have been well studied (e.g. Planque \& Fromentin 1996, Bonnet et al. 2005). They are morphologically so similar that they were not distinguished until 1958, in the Continuous Plankton Recorder (CPR) survey (Planque \& Fromentin 1996). However, their spatial distribution differs significantly (Beaugrand 2004a). C. finmarchicus is mainly located in the Atlantic Polar Biome north of the Oceanic Polar Front (Dietrich 1964, Beaugrand 2004a; present Fig. 1) while the pseudooceanic species C. helgolandicus occurs in more temperate waters south of the Oceanic Polar Front, mostly located above the European shelf-edge in the Atlantic between 40 and $60^{\circ} \mathrm{N}$ (Beaugrand 2004a, Bonnet et al. 2005). In regions where they occur together (e.g. the North Sea), the 2 species generally have different seasonal timing (Beaugrand 2003). Some studies have also reported different depth of occurrence at the same location (Bonnet et al. 2005 and references therein).

Differences in the spatial and/or temporal patterns of variability in both species of Calanus suggest differential responses to environmental variability. It is therefore important to identify their environmental preference (window or tolerance interval) and their optimum environmental level. When the preference of more than 1 factor has been determined, the ecological niche (sensu Hutchinson 1957) can be calculated (i.e. the field of tolerance of a species to the principal factors characteristic of its environment). The niche can be represented in Euclidean space with as many dimensions as factors considered. When a few numbers of parameters are used, the niche of 2 species may overlap. Increasing the number of factors reduces the relative importance of such overlap and often enables complete niche separation (Gause's competitive exclusion hypothesis: Gause 1934). Abiotic parameters are related to both geographic (e.g. topography) and water-column (e.g. nutrient concentration) factors which influence directly the physiology (e.g. growth, development and mortality rates, Carlotti et al. 1993) or reproduction (Hall \& Burns 2002, Halsband-Lenk et al. 2002) of a species. This study investigated abiotic environment and chlorophyll a concentration (as an index of available food), for which the Hutchinson ecological niche is a more suitable tool, often preferred in this type of work (e.g. Pulliam 2000, Guisan \& Wilfried 2005).

Despite the large number of studies on the biology and ecology of both Calanus finmarchicus and C. helgolandicus (e.g. Carlotti et al. 1993, Hirst \& Batten 1998, Heath et al. 1999, Bonnet et al. 2005), many gaps in our knowledge remain. Herein we employ a macroecological approach using large data sets of 11 abiotic parameters and data from the CPR survey to (1) determine the environmental optimum level of both species for each environmental parameter, (2) quantify the influ- 
ence of each parameter on both species, (3) identify and (4) calculate the breadth of their ecological niches. The temporal stability of the temperature profiles of both species is also investigated. A baseline is provided for use in forecasting modifications in the abundance and spatial distributions of the 2 species that can be expected with global climate change.

\section{MATERIALS AND METHODS}

Biological data. Data on the abundance of Calanus finmarchicus and C. helgolandicus were provided by the CPR survey, a large-scale plankton monitoring programme initiated by Sir Alister Hardy in 1931. The CPR is a robust instrument designed for use by seamen on commercial ships. Management and maintenance of the survey have been carried out by the English laboratory (Sir Alister Hardy Foundation for Ocean Science [SAHFOS]) since 1990. CPR instruments are towed at a depth of $7 \mathrm{~m}$ (Reid et al. 2003a) and the survey has monitored plankton ecosystems at this depth only (Batten et al. 2003). Therefore, it might be dangerous to infer Hutchinson's ecological niche from a single depth. However, calanoid copepods migrate vertically (Daro 1985) and because CPR sampling is carried out both day and night, it is unlikely that this process greatly influenced the measurement of the Hutchinson ecological niche in this study.

Water enters the CPR through an inlet aperture of $1.61 \mathrm{~cm}^{2}$ and passes through a $270 \mu \mathrm{m}$ silk-covered filtering mesh (Batten et al. 2003). Individuals $>2 \mathrm{~mm}$, such as Copepodite Stages CV and CVI of Calanus finmarchicus and $C$. helgolandicus are then removed from the filter and covering silk. Generally, all individuals are counted, but for particularly dense samples a sub sample is taken (Batten et al. 2003). The data used in this study correspond to Copepodite Stages CV and CVI. Studies have shown that near surface sampling provides a satisfactory representation of the epipelagic zone (Batten et al. 2003). This programme has accumulate one of the greatest databases on marine plankton worldwide. Currently, about 200000 samples have been analysed, providing information on the presence and/or abundance of more than 400 plankton species every month since 1946 in both the temperate and subpolar region of the North Atlantic Ocean.

Environmental data. We investigated the area from Longitude $99.5^{\circ} \mathrm{W}$ to $19.5^{\circ} \mathrm{E}$ and Latitude $29.5^{\circ}$ to $69.5^{\circ} \mathrm{N}$. Eleven parameters were chosen (Table 1). Sea surface temperature (SST) was essential as it has a well-documented effect on plankton (e.g. Reid \& Edwards 2001). Wind-induced water turbulence was used as an indicator because it has been shown that wind, by its impact on water-column stability, affects plankton populations (Heath et al. 1999). The index of turbulence and SST was aquired from the Comprehensive Ocean-Atmosphere Data Set (COADS) and was downloaded from the internet site of the National Oceanographic Data Center (NODC) (Woodruff et al. 1987), which manages acquisition, controls quality and safeguards the data.

Salinity also constitutes an important limiting factor for many species. Data on this parameter, and on silicates, phosphates, nitrates and dissolved oxygen were downloaded from the World Ocean Atlas 2001 (WOA1) database for a depth of $10 \mathrm{~m}$.

Bathymetry was selected because it has been suggested that this parameter influences the distribution of some copepod species (Beaugrand et al. 2001). Bathymetry data originate from the database 'General Bathymetric Chart of the Oceans' (GEBCO). Spatial variability in bathymetry was assessed over the study area. First, the mean and SD of bathymetry data were calculated in a geographical cell of $1^{\circ}$ latitude and $1^{\circ}$ longitude, (225 data per geographical cell). Then, the coefficient of variation of bathymetry $\left(\mathrm{CV}_{\mathrm{B}}\right)$ was calculated as:

$$
\mathrm{CV}_{\mathrm{B}}=\frac{S_{\mathrm{B}}}{m_{\mathrm{B}}}
$$

where $m_{\mathrm{B}}$ is the average and $S_{\mathrm{B}}$ the SD for bathymetry in each geographical cell. There was generally high variability in bathymetry over the continental slope regions.

Chlorophyll is a potentially influential parameter because the 2 selected species are mainly herbivorous (Mauchline 1998). However as Kleppel (1993) showed and Mauchline (1998) stressed, the dietary requirements of copepods change from the first nauplii stage to the adult stage and are likely to vary at both diel and seasonal scales. Furthermore, it is likely that both Calanus species also feed on microzooplankton (Mauchline 1998). Therefore, chlorophyll content should only be considered as an index of food availability. Chlorophyll values originated from the programme 'Sea-viewing Wide Field-of-view Sensor' (SeaWIFS) from the National Aeronautics and Space Administration (NASA).

The mixed-layer depth (MLD) is another indicator of water column stability. In contrast to the index of turbulence, this parameter is obtained from vertical profiles of temperature and salinity. MLD data come from a compilation of about 4.5 million profiles gathered by the NODC and World Ocean Circulation Experiment (WOCE). These profiles are the result of the analysis of data from 1941 to 2002 and originate from various measuring instruments such as the conductivity-temperature-depth (CTD) monitor, mechanical bathythermograph (MBT) or expendable bathythermograph (XBT). 
Table 1. Origin and characteristics of environmental data used in this study.

\begin{tabular}{|c|c|c|c|c|c|}
\hline Data & Units & Spatial resolution & Type & $N\left(\times 10^{6}\right)$ & Source \\
\hline Biotic & $\begin{array}{l}\text { Individual } \\
\text { number }\end{array}$ & (no grid) & $\begin{array}{l}\text { Each month } \\
\text { for } 1946-2002\end{array}$ & $\begin{array}{l}0.2 \text { per } \\
\text { species }\end{array}$ & $\begin{array}{c}\text { Sir Alister Hardy Foundation } \\
\text { for Ocean Science }\end{array}$ \\
\hline $\begin{array}{l}\text { Sea surface } \\
\text { temperature }\end{array}$ & ${ }^{\circ} \mathrm{C}$ & $\begin{array}{c}260.5^{\circ} \text { to } 29.5^{\circ} \mathrm{E} \\
69.5^{\circ} \text { to } 30.5^{\circ} \mathrm{N} \\
\left(\text { each } 1^{\circ}\right)\end{array}$ & $\begin{array}{l}\text { Monthly mean } \\
\text { 1960-2002 }\end{array}$ & 33.5 & $\begin{array}{c}\text { National Oceanographic } \\
\text { Data Center (COADS) }\end{array}$ \\
\hline $\begin{array}{l}\text { Wind-induced } \\
\text { turbulence index }\end{array}$ & $\mathrm{m}^{3} \mathrm{~s}^{-3}$ & $\begin{array}{c}260.5^{\circ} \text { to } 29.5^{\circ} \mathrm{E} \\
69.5^{\circ} \text { to } 30.5^{\circ} \mathrm{N} \\
\left(\operatorname{each} 1^{\circ}\right)\end{array}$ & $\begin{array}{l}\text { Monthly mean } \\
1960-2002\end{array}$ & 33.5 & $\begin{array}{c}\text { National Oceanographic } \\
\text { Data Center (COADS) }\end{array}$ \\
\hline Salinity & & $\begin{array}{c}99.5^{\circ} \mathrm{W} \text { to } 19.5^{\circ} \mathrm{E} \\
89.5^{\circ} \text { to } 10.5^{\circ} \mathrm{N} \\
\left(\text { each } 1^{\circ}\right)\end{array}$ & $\begin{array}{l}\text { Monthly mean } \\
\text { (climatology) }\end{array}$ & 2.8 & World Ocean Atlas (2001) \\
\hline Silicate & $\mu \mathrm{mol} \mathrm{l} \mathrm{l}^{-1}$ & $\begin{array}{c}99.5^{\circ} \mathrm{W} \text { to } 19.5^{\circ} \mathrm{E} \\
89.5^{\circ} \text { to } 10.5^{\circ} \mathrm{N} \\
\left(\text { each } 1^{\circ}\right)\end{array}$ & $\begin{array}{l}\text { Monthly mean } \\
\text { (climatology) }\end{array}$ & 2.8 & World Ocean Atlas (2001) \\
\hline Phosphate & $\mu \mathrm{mol} 1^{-1}$ & $\begin{array}{l}99.5^{\circ} \mathrm{W} \text { to } 19.5^{\circ} \mathrm{E} \\
89.5^{\circ} \mathrm{N} \text { to } 10.5^{\circ} \mathrm{N} \\
\left(\text { each } 1^{\circ}\right)\end{array}$ & $\begin{array}{l}\text { Monthly mean } \\
\text { (climatology) }\end{array}$ & 2.8 & World Ocean Atlas (2001) \\
\hline Nitrate & $\mu \mathrm{mol} 1^{-1}$ & $\begin{array}{c}99.5^{\circ} \mathrm{W} \text { to } 19.5^{\circ} \mathrm{E} \\
89.5^{\circ} \text { to } 10.5^{\circ} \mathrm{N} \\
\left(\text { each } 1^{\circ}\right)\end{array}$ & $\begin{array}{l}\text { Monthly mean } \\
\text { (climatology) }\end{array}$ & 2.8 & World Ocean Atlas (2001) \\
\hline Dissolved oxygen & $\mathrm{ml} \mathrm{l}^{-1}$ & $\begin{array}{c}99.5^{\circ} \mathrm{W} \text { to } 19.5^{\circ} \mathrm{E} \\
89.5^{\circ} \text { to } 10.5^{\circ} \mathrm{N} \\
\left(\text { each } 1^{\circ}\right)\end{array}$ & $\begin{array}{l}\text { Monthly mean } \\
\text { (climatology) }\end{array}$ & 2.8 & World Ocean Atlas (2001) \\
\hline Bathymetry & $\mathrm{m}$ & $\begin{array}{c}80^{\circ} \mathrm{W} \text { to } 20^{\circ} \mathrm{E} \\
90^{\circ} \text { to } 10^{\circ} \mathrm{N} \\
\text { each } 0.4^{\circ}\end{array}$ & $\begin{array}{l}\text { Monthly mean } \\
\text { (climatology) }\end{array}$ & 27.4 & $\begin{array}{c}\text { General Bathymetric Chart } \\
\text { of the Oceans }\end{array}$ \\
\hline $\begin{array}{l}\text { Spatial variability } \\
\text { in the bathymetry }\end{array}$ & $\mathrm{m}$ & $\begin{array}{c}99.5^{\circ} \mathrm{W} \text { to } 19.5^{\circ} \mathrm{E} \\
69.5^{\circ} \text { to } 29.5^{\circ} \mathrm{N} \\
\left(\text { each } 1^{\circ}\right)\end{array}$ & $\begin{array}{l}\text { Monthly mean } \\
\text { (climatology) }\end{array}$ & 0.058 & $\begin{array}{c}\text { General Bathymetric Chart } \\
\text { of the Oceans }\end{array}$ \\
\hline Chlorophyll a & $\mathrm{mg} \mathrm{m}^{-3}$ & $\begin{array}{c}100^{\circ} \mathrm{W} \text { to } 30^{\circ} \mathrm{E} \\
70^{\circ} \text { to } 40^{\circ} \mathrm{N} \\
\text { each } 0.5^{\circ}\end{array}$ & $\begin{array}{l}\text { Monthly mean } \\
1997-2002\end{array}$ & 18.8 & $\begin{array}{l}\text { Sea-viewing Wide Field-of- } \\
\text { view Sensor (SeaWIFS) }\end{array}$ \\
\hline Mixed-layer depth & $\mathrm{m}$ & $\begin{array}{c}179.5^{\circ} \mathrm{W} \text { to } 179.5^{\circ} \mathrm{E} \\
89.5^{\circ} \mathrm{N} \text { to } 89.5^{\circ} \mathrm{S} \\
\left(\text { each } 1^{\circ}\right)\end{array}$ & $\begin{array}{l}\text { Monthly mean } \\
\text { 1941-2002 }\end{array}$ & 0.8 & $\begin{array}{c}\text { World Ocean Circulation } \\
\text { Experiment }\end{array}$ \\
\hline
\end{tabular}

Pre-processing of data. The first stage of the analysis consisted of homogenising both environmental and biological variables. All original data tables were converted into 3 types of matrix: (1) matrices $(2.48$ million data points) with data for each month and year for the period 1960 to 2002 (temperature, wind stress); (2) matrices (57600 data points) with data for each month (nutrients, oxygen, chlorophyll, MLD) based on the average of time periods ranging from 5 to $43 \mathrm{yr}_{\mathrm{i}}$ (3) matrices (4800 data points) with no information on time (bathymetry and its spatial variability). The 3 types of environmental grids were used to regularise biological data, and no spatial interpolation was made. An arithmetic mean was calculated when the number of data for a given location and time period was $>1$.
Statistical analyses. Fig. 2 summarises the different statistical analyses performed in this study.

Analysis 1-Characterisation of environmental optima at seasonal scale: The optimum of each species was identified for each environmental variable (a total of 22 environmental profiles: 2 species $\times 11$ environmental parameters). A profile was a contour diagram of a matrix of $12 \mathrm{mo} \times \mathrm{n}$ environmental categories. To determine the number of environmental categories, the minimum and maximum values were first calculated. Then, intervals were chosen by trial and error as a compromise between the resolution of the profile and the increasing number of missing data with increasing resolution. The profile matrix was assessed by averaging abundance data for each month and environmental category. Abundance data were log-trans- 


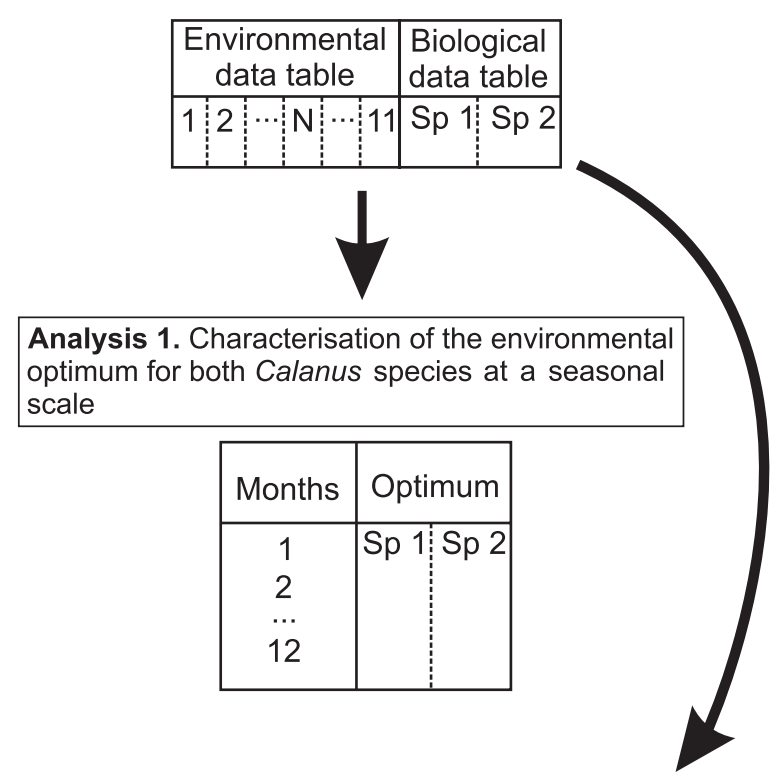

Analysis 2. Quantification of the importance of each environmental parameter by PCA at a seasonal scale

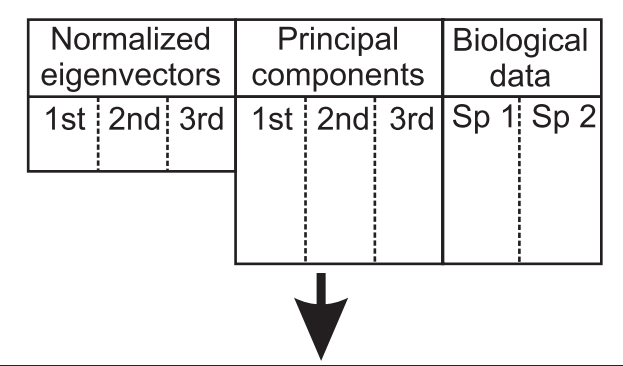

Analysis 3. Identification of the ecological niche of both Calanus species at a seasonal scale

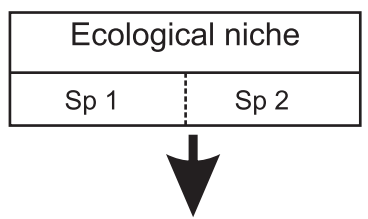

Analysis 4. Quantification of the breadth of the ecological niche and comparison for each species at a seasonal scale

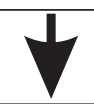

Analysis 5. Thermal profile of both Calanus species as a function of the state of the North Atlantic Oscillation

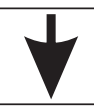

Analysis 6. Thermal profile of both Calanus species as a function of CPR data for daylight and dark periods

Fig. 2. Calanus finmarchicus and C. helgolandicus. Summary of statistical analyses performed in this study. PCA: principal component analysis; CPR: Continuous Plankton Recorder formed $\left(\log _{10}[x+1]\right)$ to limit the effect of extreme values.

Analysis 2-Quantification of importance of each environmental parameter at seasonal scale: A principal components analysis (PCA) was used to quantify the influence of each abiotic factor and chlorophyll concentration (used herein as an index of available food) on spatial and seasonal changes in Calanus spp. abundance at the scale of the North Atlantic Ocean (Fig. 2). An algorithm that took into consideration missing data was used to calculate the eigenvectors (Bouvier 1977). This method of ordination made possible a summary of multivariate information in a reduced number of dimensions, i.e. the principal components (Jolliffe 1986). The normalised eigenvectors allowed identification of the variables contributing most to the principal components. The PCA was calculated from (120 longitudes $\times 40$ latitudes $\times 12 \mathrm{mo}) \times 11$ environmental variables. The spatial grid had a resolution of $1^{\circ}$ longitude and $1^{\circ}$ latitude. This table was centred and reduced prior to application of the analysis to remove any effect of scale between environmental variables.

Analysis 3-Identification of ecological niche at seasonal scale: To identify the ecological niche of both species, we used the first 3 principal components. The concept of ecological niche used in this study is that of Hutchinson (1957) which states that the niche is the field of tolerance of a species to the principal factors of its environment. The concept has been refined here by the recent improvements discussed by Frontier et al. (2004). In particular, our analysis takes into account that some factors are not independent but covary either positively or negatively. The use of principal components decreases the effect of multicollinearity in the data (Legendre \& Legendre 1998). We repeated the procedure used in Analysis 1 to map the ecological niche of both Calanus species as a function of principal components (linear combination of environmental factors).

Analysis 4-Quantification and comparison of Hutchinson's niches: Quantification and comparison of Hutchinson's niche for both Calanus species were performed for 4 different categories of abundance. The first category was based on all presence data: the value of the 11 environmental variables was retained when an individual (C. finmarchicus or C. helgolandicus) was recorded in a geographical cell within the environmental grid of $1 \times 1^{\circ}$ (Longitude $99.5^{\circ} \mathrm{W}$ to $19.5^{\circ} \mathrm{E}$, Latitude $29.5^{\circ} \mathrm{N}$ to $69.5^{\circ} \mathrm{N}$ ); a total of 24 subsets was determined (12 mo $\times 2$ species). A similar procedure was applied to the other 3 categories. The second category comprised Calanus spp. data greater than the first quartile, the third category Calanus spp. data greater than the median and the fourth category data for Calanus spp. greater than the third quartile. The breadth of the niche thereby decreased from Category 1 to Category 4 . The 
quartiles and median were assessed from the biological data table in Fig. 2. Therefore, the quantification and comparison of Hutchinson's niche for the 2 species used $96(24 \times 4)$ subsets.

To assess and compare Hutchinson's niche for the 2 Calanus species, we used a numerical analysis based on 'multiple response permutation procedures' (MRPP) and recently applied to determine the ecological niche by G. Beaugrand \& P. Helaouët (unpubl. data). The method quantifies the breadth of the niche of the 2 species and tests if their niches are statistically different. First, quantification of the niche was made by calculating the mean Euclidean distance for each subset based on the 11 environmental parameters. The higher the mean Euclidean value, the greater Hutchinson's niche. Second, for a given month and category, a weighted mean of the Euclidean distance of both species niche was calculated. Then, the weighted distance was tested by permutations of original subset. A value of 10000 permutations was selected. For each simulation, the weighted distance was recalculated and the probability that the separation of the niches of $C$. finmarchicus and $C$. helgolandicus wouold be significant was represented by the number of times the recalculated weighted distance was inferior to that observed.

Analysis 5-Calanus thermal profiles as a function of state of North Atlantic Oscillation (NAO) and 1987 regime shift: One important issue was to determine whether Hutchinson's niche was constant at a decadal scale and whether it was in-

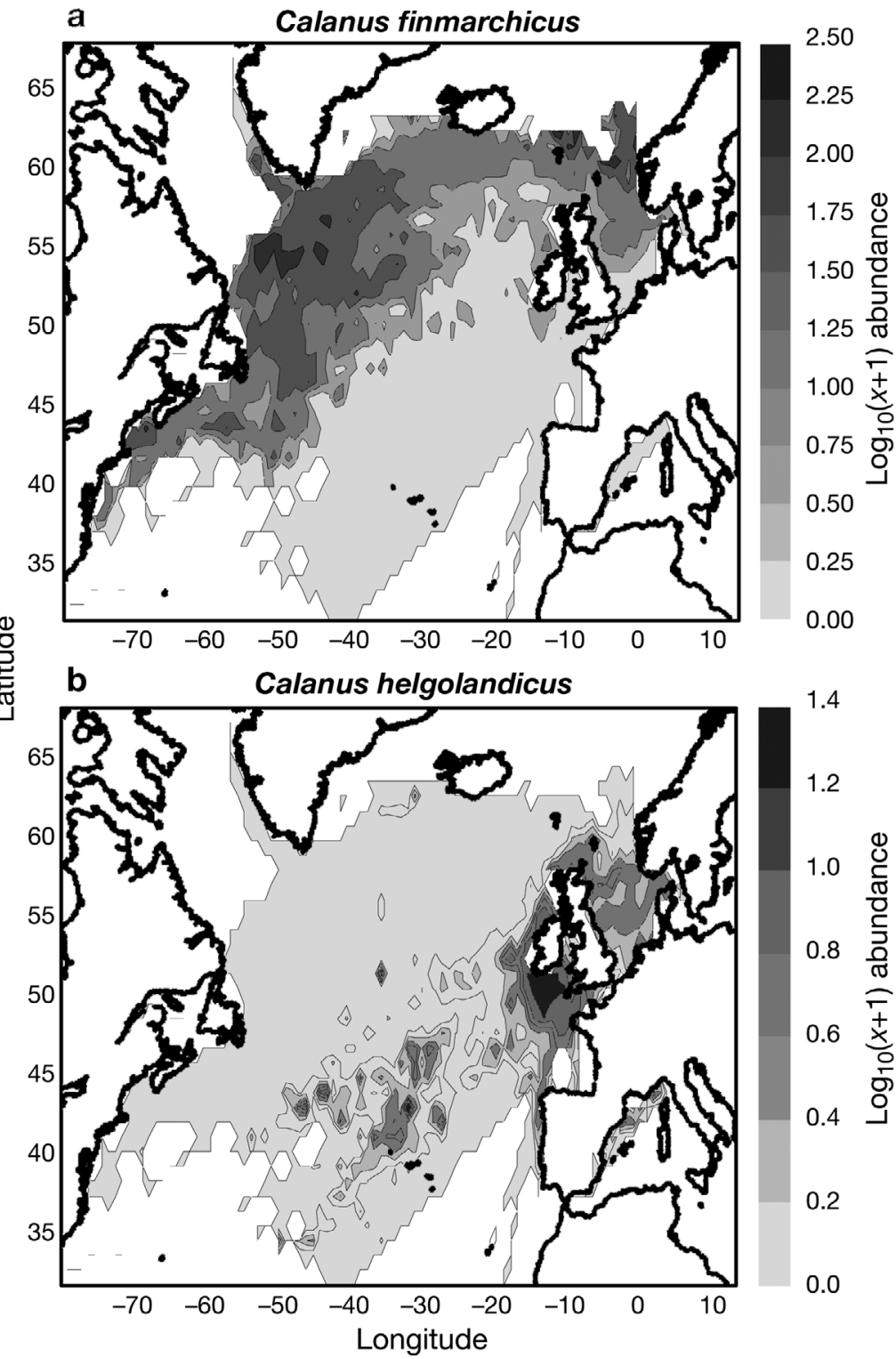
fluenced by climate variability during the

Fig. 3. (a) Calanus finmarchicus and (b) C. helgolandicus. Spatial distribution in North Atlantic Ocean. No interpolation made

period of investigation (1958 to 2002). In the latter case, the species should be able to acclimatise quickly to climate change. To test this, we calculated the thermal profile of both species for negative NAO (NAO index $<-1)$, medium NAO $(-1 \leq$ NAO index $\leq 1)$ and positive NAO (NAO index $>1$ ). Thermal profiles were calculated according to a procedure identical to Analysis 1. To examine the potential impact of the regime shift in the North Sea (Beaugrand 2004b), thermal profiles were also assessed for years prior to and after 1987.

Analysis 6-Calanus thermal profiles as a function of CPR data for daylight and dark periods. Changes in the depth distribution of Calanus spp. through time could bias our assessment of Hutchinson's niche, as the CPR survey samples at a standard depth of about $7 \mathrm{~m}$.
To evaluate if this process could have significantly affected ours results, we assessed the thermal profile (Analysis 1) of both species for CPR samples collected during daylight (CPR samples collected between 10:00 and 16:00 h) and dark (CPR samples collected between 22:00 and 04:00 h) (Beaugrand et al. 2001; their Fig. 1).

\section{RESULTS}

\section{Spatial distribution of biological and environmental data}

Fig. 3 shows the mean spatial distribution of Calanus finmarchicus and C. helgolandicus for the period 1958 
a SST $\left({ }^{\circ} \mathrm{C}\right)$

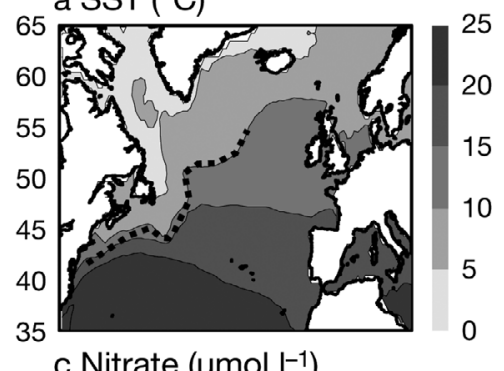

c Nitrate $\left(\mu \mathrm{mol} \mathrm{I}^{-1}\right)$
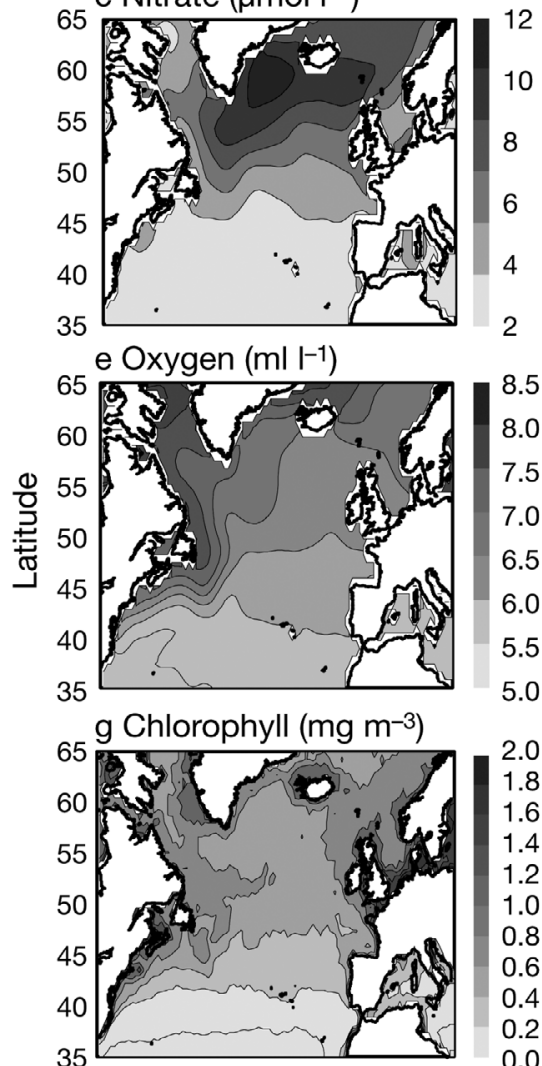

i Silicate $\left(\mu \mathrm{mol} \mathrm{l}^{-1}\right)$

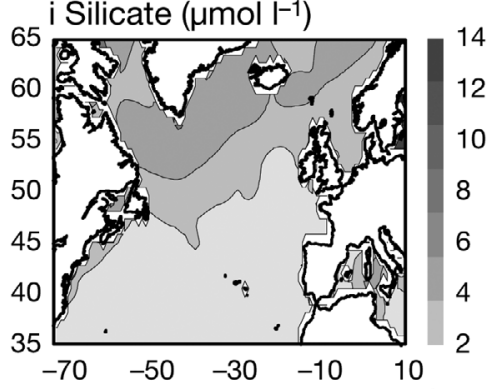

b Salinity

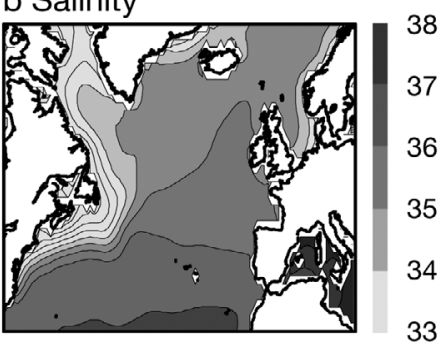

d Phosphate $\left(\mu \mathrm{mol} \mathrm{l^{-1 } )}\right.$

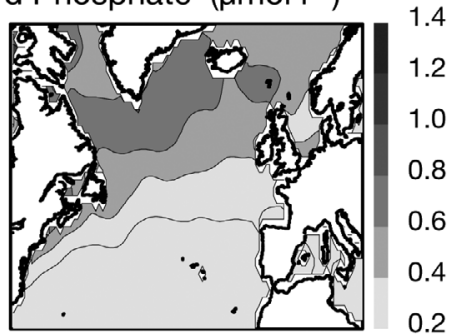

f Turbulence $\left(\mathrm{m}^{3} \mathrm{~s}^{-3}\right)$

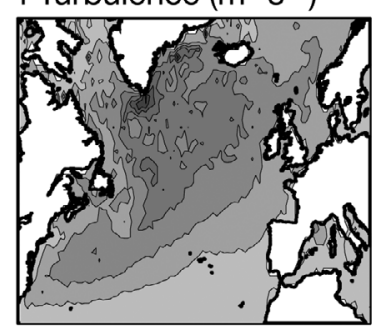

h Mixed layer depth $(\mathrm{m})$

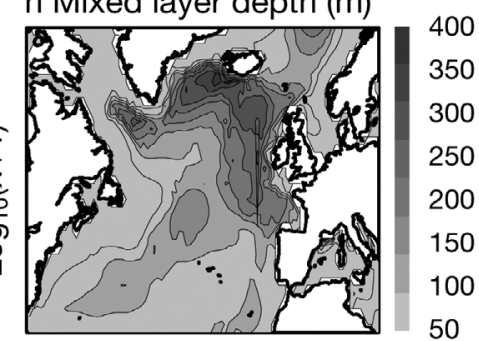

j Bathymetry $(\mathrm{m})$

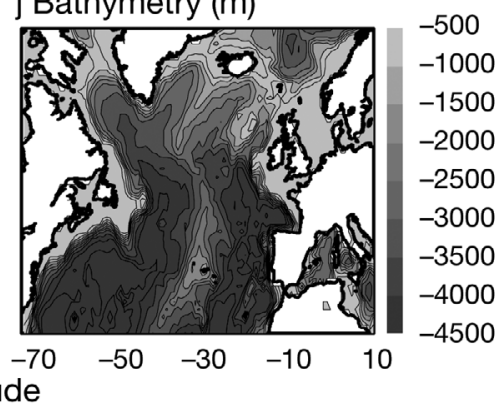

Fig. 4. Spatial distribution of (a) mean sea surface temperature (SST), (b) salinity, (c) nitrate, (d) phosphate, (e) dissolved oxygen, (f) turbulence, (g) chlorophyll $a_{1}$ (h) mixed-layer depth, (i) silicate, (j) bathymetry. Location of the Oceanic Polar Front is superimposed on (a) (thick dotted line)

to 2002. The spatial distribution of $C$. finmarchicus (Fig. 3a) was located north of the Oceanic Polar Front (Dietrich 1964) with 2 main centres of distribution south of the Labrador Sea and in oceanic regions south and west of Norway (Fig. 3a). Fig. 3a suggests that this species is an indicator of the Atlantic Polar Biome and especially the Atlantic Arctic Province and the Atlantic Subarctic Province as defined by Longhurst (1998). The spatial distribution of $C$. helgolandicus differed (Fig. 3b), being mainly centred along the shelf-edge in temperate regions. Fig. 4 presents the mean values of the environmental parameters in the North Atlantic Ocean. Temperature is an important driving mechanism for C. finmarchicus, while it probably has a more limited role for C. helgolandicus (Fig. 4j).

\section{Environmental profiles \\ Monthly thermal profile}

Fig. 5 shows the thermal profile of Calanus finmarchicus (Fig. 5a) and of $C$. helgolandicus (Fig. 5b) for each month. C. finmarchicus had its maximal abundance between April and September at temperatures ranging from 6 to $10^{\circ} \mathrm{C}$. C. helgolandicus had a tolerance range between 11 and $16^{\circ} \mathrm{C}$, especially in spring (Fig. 5b). A remarkable feature was that the optimum varied seasonallyfor both species. Each species had a clear distinct thermal optimum. The tolerance interval for $C$. finmarchicus was greater than that of its congener. Fig. 5c shows the mean abundance of $C$. finmarchicus and $C$. helgolandicus as a function of temperature. The complementarity in the distribution of the 2 species is significant. The results show that a temperature change in a region with an annual thermal regime of about $10^{\circ} \mathrm{C}$ could trigger a shift from a system dominated by C. finmarchicus to a system dominated by C. helgolandicus.

\section{Other profiles}

Fig. 6 presents further environmental profiles. Salinity profiles separated the 2 Calanus species well (Fig. 6a). C. finmarchicus had its maximal abundance at salinities between 33.8 and 35 in the spring and summer months. The salinity optimum was higher for C. helgolandicus (35 to 35.5). Dis- 

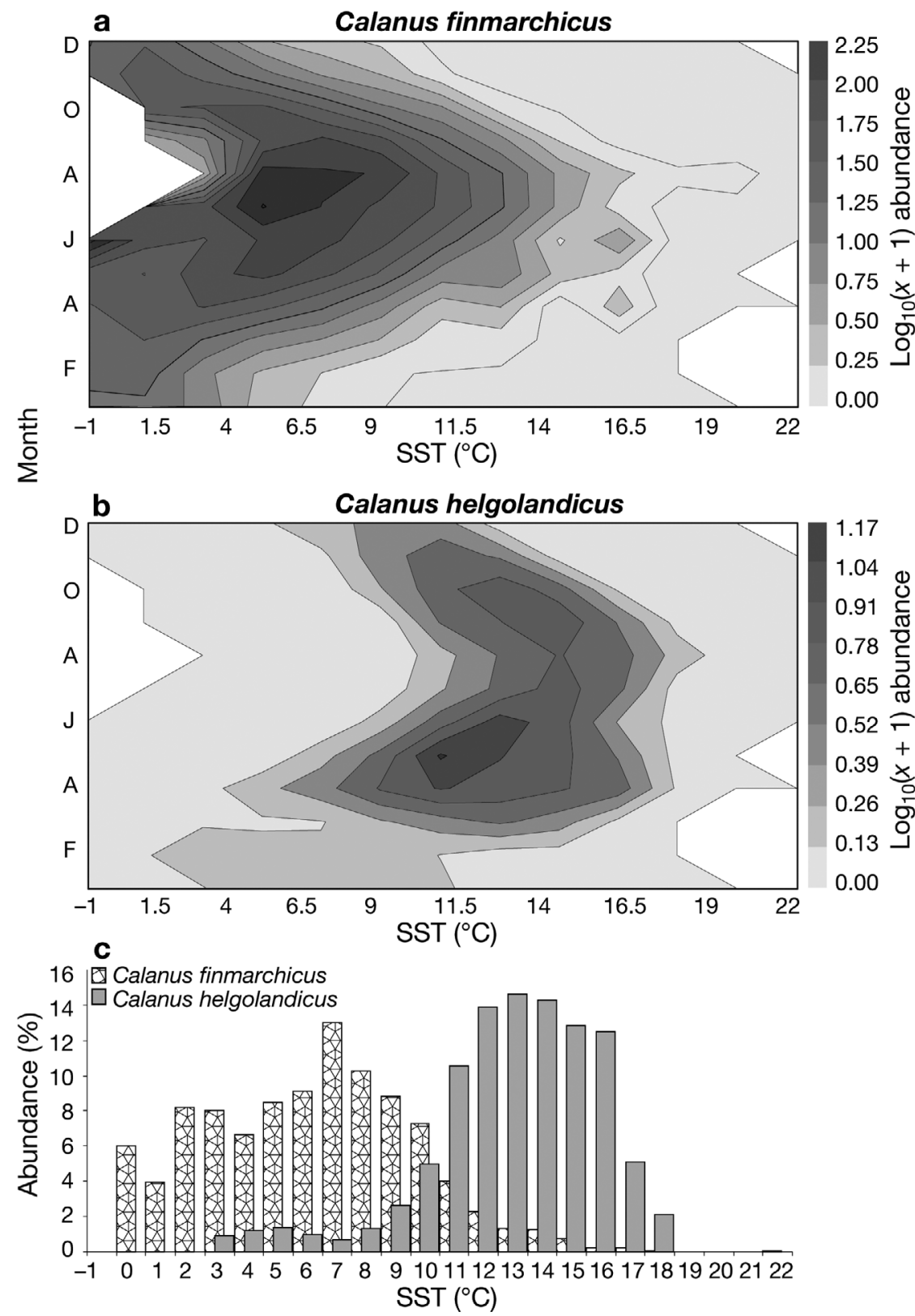

Fig. 5. Calanus finmarchicus and C. helgolandicus. $(\mathrm{a}, \mathrm{b})$ Contour diagram of abundance (decimal logarithm) as a function of SST and month of year, and (c) histogram showing percent relative average abundance as a function of SST

high abundance of $C$. helgolandicus was located in a more restricted tolerance range and time interval. Other nutrient profiles (nitrate and silicate; not shown) showed that C. finmarchicus occured in waters containing more nutrients than its congener. C. finmarchicus was located in waters with a higher index of turbulence than C. helgolandicus (data not shown). Similar results were found for the mixedlayer depth (data not shown).

Calanus finmarchicus was mainly abundant at depths ranging from 269 to $3513 \mathrm{~m}$, but can be found in regions of low bathymetry (Fig. 7a). The species was primarily found in regions with low to medium spatial variability in bathymetry. C. helgolandicus was more often found in regions characterised by a bathymetry between 82 and $1216 \mathrm{~m}$, despite the fact that a second mode was detected at depths $>4000 \mathrm{~m}$ (Fig. 7b). This last mode was probably related to expatriate individuals in the region near the Bay of Biscay (see Fig. 3b). The species was identified in regions characterised by a higher spatial variability in bathymetry, reinforcing its classification as pseudo-oceanic (i.e. occurring in both neritic and oceanic regions but is mainly abundant above the shelf-edge).

\section{Quantification of factors influencing spatial distribution}

A PCA was calculated for each variable from 4800 12-mo geographical squares $\times 11$ variables.

solved oxygen content also distinguished the 2 species (Fig. 6b). Abundance of C. finmarchicus was maximal at 6.4 to $7.3 \mathrm{ml} \mathrm{l}^{-1}, C$. helgolandicus was found in water with less oxygen (5.9 to $6.6 \mathrm{ml} \mathrm{l}^{-1}$ ). Chlorophyll a concentration did not completely, separate the species (Fig. 6c). Nutrients were also examined. Fig. 6d shows an example of a profile for phosphate. Higher abundance of $C$. finmarchicus corresponded to phosphate

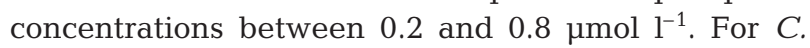
helgolandicus, the optimum was between 0.1 and $0.3 \mu \mathrm{mol} \mathrm{l}^{-1}$. As in the case of salinity and temperature,
The first axis explained $42.3 \%$ of the total variance, the second $20.8 \%$, the third $9.5 \%$ and the fourth $7.2 \%$. The calculation of equiprobability $(E)$ :

$$
E=\left(\frac{1}{N}\right) \times 100
$$

where $N$ is the number of variables, indicated that all axes with a variance of more than $9.1 \%$ can be considered significant. Therefore, only the first 3 normalised eigenvectors and principal components (representing $72.6 \%$ of the total variance) were retained. Fig. 8 presents a scatterplot of the first 2 normalised eigenvectors 
Calanus finmarchicus

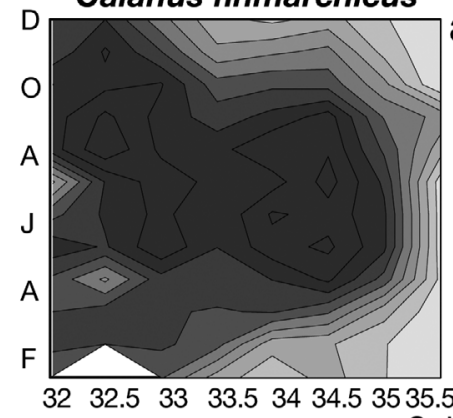

Calanus helgolandicus
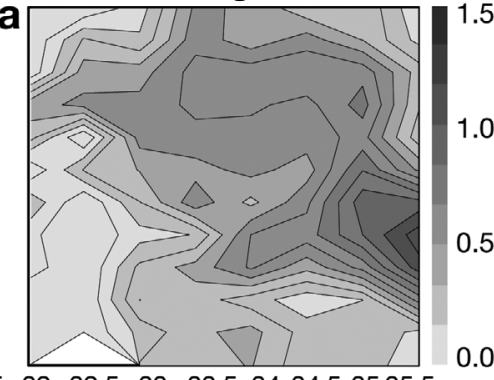

Salinity

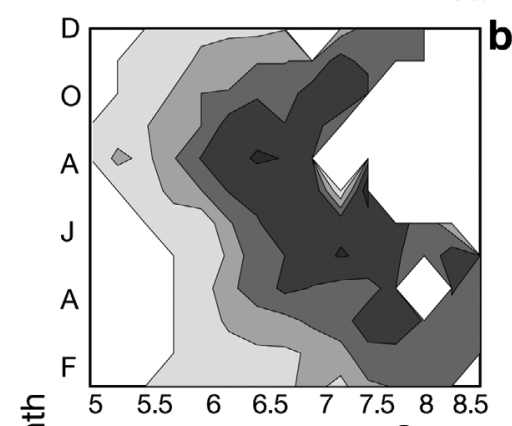

岳
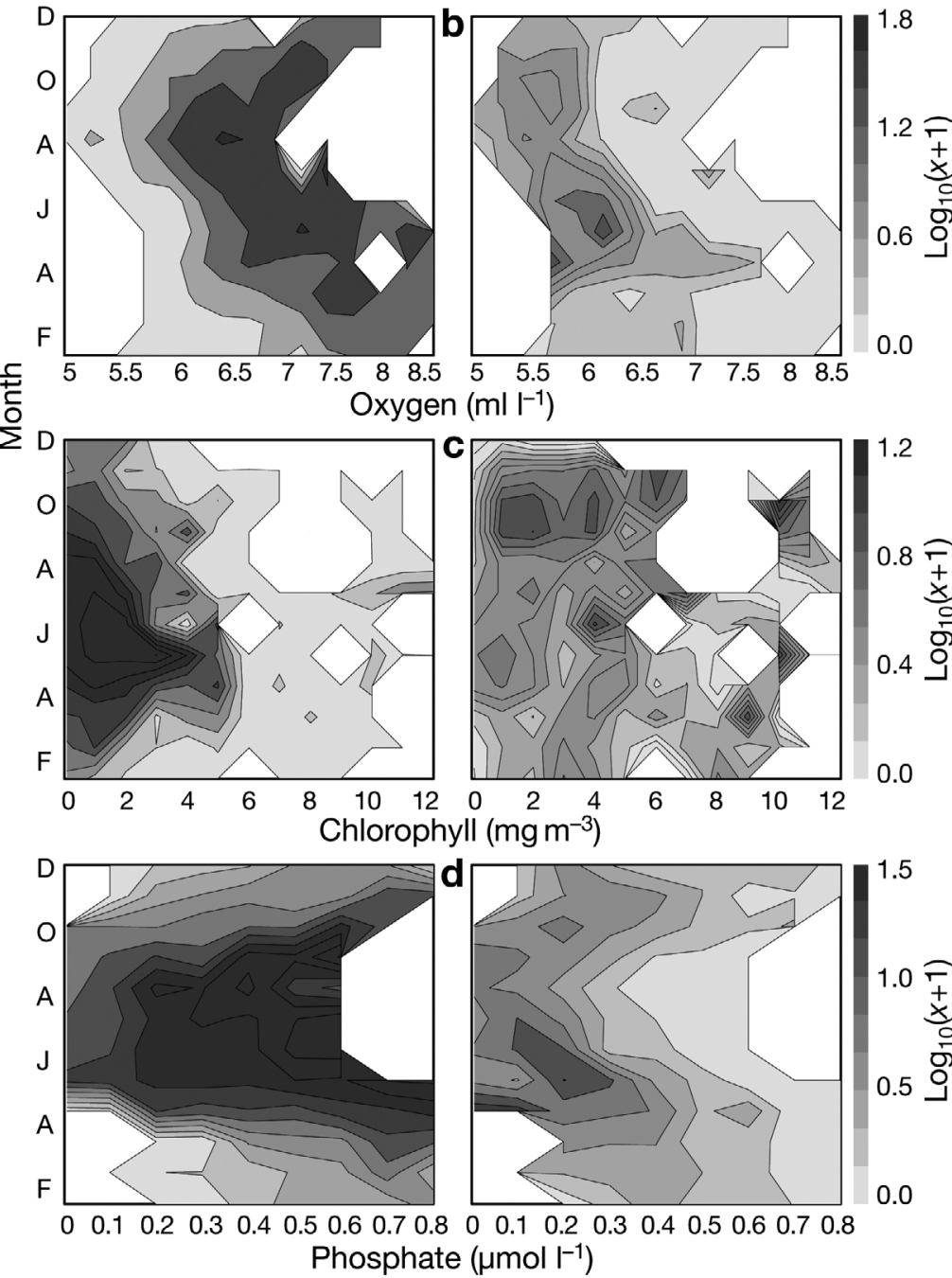

Fig. 6. Calanus finmarchicus and C. helgolandicus. Abundance (in decimal logarithm) as a function of month of year and of (a) salinity, (b) dissolved oxygen, (c) chlorophyll $a_{1}$ (d) phosphate

and maps of the first principal component. Variables such as temperature (relative contribution, $\mathrm{RC}=82 \%$ ); phosphate $(\mathrm{RC}=75.1 \%)$, oxygen $(\mathrm{RC}=73.8 \%)$, silicate $(\mathrm{RC}=62.9 \%)$ and nitrate $(\mathrm{RC}=54.7 \%)$ contributed greatly to the first component. Temperature was correlated negatively with the above factors (Fig. 8a). Map-
$1.0 \overparen{F}$ $0.5 \stackrel{\circ}{\circ}$

1.8

0.0

ping of the first principal component identified a northward change from March to August and then a reverse movement from September to December (Fig. 8b). The Oceanic Polar Front (Dietrich 1964) was clearly identified (for location see Fig. 1). An asymmetry in the seasonal changes of the physical-chemical parameters was detected. The northern limit of the western part of the Atlantic basin remained relatively constant at a monthly scale while in the eastern part the seasonal northward movement was much more pronounced. The influence of bathymetry on the first principal component was not detected.

Fig. 9 is a scatterplot of the second and third normalised eigenvectors and maps of the seasonal changes in the second principal component at a seasonal scale. Variables that contributed mostly to the second principal component were mixedlayer depth $(\mathrm{RC}=51.1 \%)$, index of turbulence $(\mathrm{RC}=43.7 \%)$ and, to a lesser extent, chlorophyll concentration $(\mathrm{RC}=27.1 \%)$, the index of spatial variability in bathymetry $(\mathrm{RC}=23.2 \%)$ and average bathymetry ( $\mathrm{RC}=22.9 \%$ ). Mapping of seasonal changes in the second principal component (Fig. 9b) showed the importance of parameters related to water-column structure and the stable-biotope component (i.e. geographically stable, e.g. variables related to bathymetry). The effect of water-column structure was especially strong in the Atlantic Arctic Biome.

Fig. 10a shows that the main parameter related to the third principal component was primarily the index of spatial variability in bathymetry $(\mathrm{RC}=42.4 \%)$ so that the third principal component (Fig 10b) directly highlighted the bathymetry of the region.

\section{Identification of ecological niche}

Using the first 3 principal components, a representation of the ecological niche (sensu Hutchinson 1957) is outlined in Fig. 11, which suggests that the ecological niche of both Calanus species is well separated. The graphical was confirmed by the MRPP-based test, which indicated a statistically significant separation of the niche for each month and abundance category (Table 2). Quantification of the breadth of the niche further indicated that the niche breadth of $C$. finmarchicus 


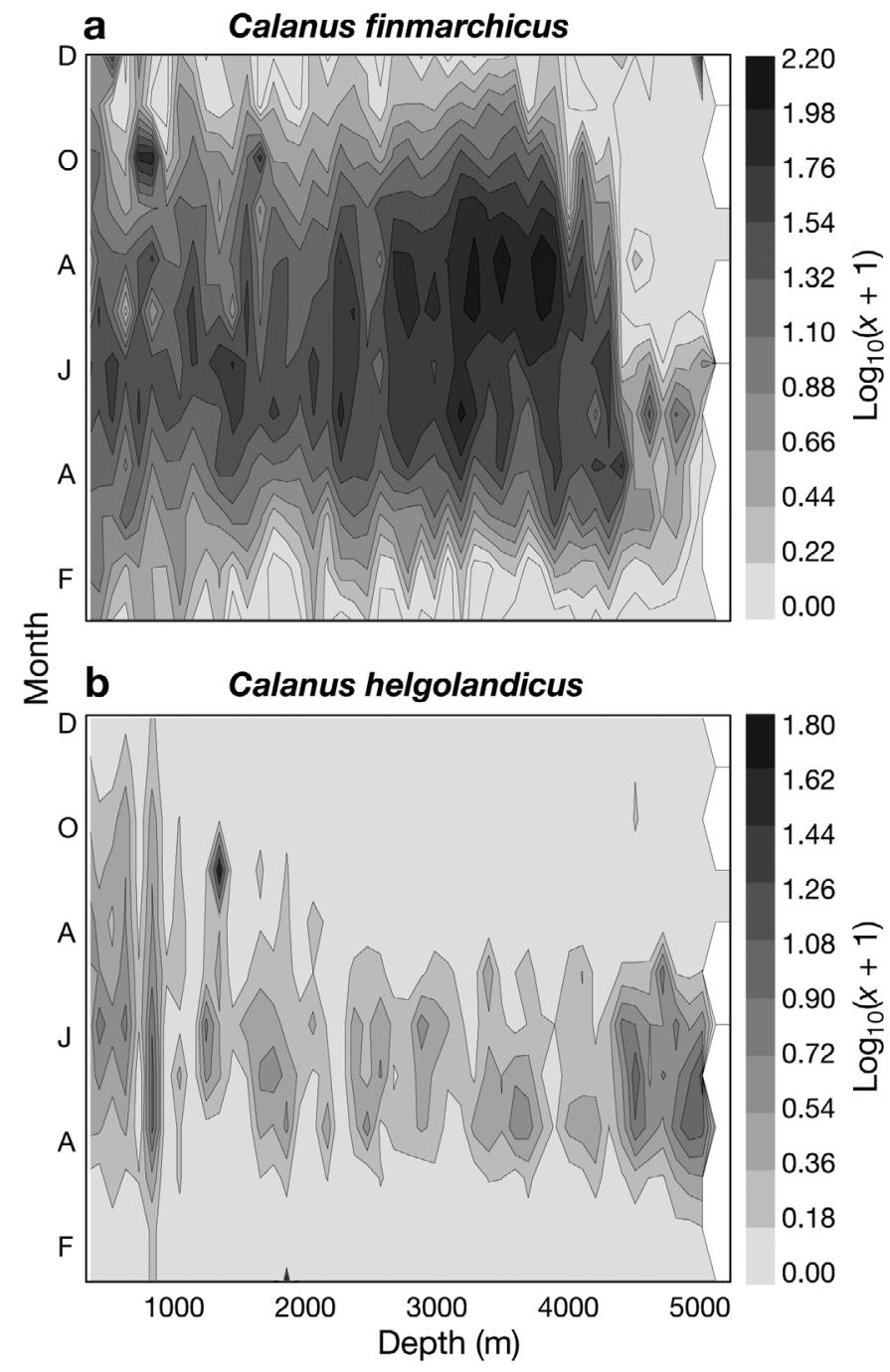

Fig. 7. (a) Calanus finmarchicus and (b) C. helgolandicus. Abundance (decimal logarithm) as a function of bathymetry and month of year was overall larger (e.g. niche breadth index $=8.2$ for January) than that of its congener (e.g. niche breadth index $=7.4$ for January) when the estimation was based on presence data, whatever the month. When higher categories of abundance were considered, few exceptions were detected; these corresponded to the main seasonal maximum of the 2 species. These exceptions might be related to the positive relationship between dispersal and abundance of the 2 species.

\section{Application of ecological niche approach to explain change in dominance}

Temperature was the most important environmental parameter according to PCA results. This parameter separated the 2 species well. Fig. 12 shows changes in the proportion of Calanus helgolandicus as \% of total Calanus (C. finmarchicus and C. helgolandicus) as a function of temperature. The location of the line below which $10 \%$ of Calanus identified by the CPR survey were $C$. helgolandicus varied monthly. Fig. 12 shows that a change in Calanus dominance (from 10 to $60 \%$ for C. helgolandicus) occurs when temperature increases by 1.5 to $3^{\circ} \mathrm{C}$ during the reproductive season. Superimposed on the contour diagram, the minimal and maximal temperatures in the North Sea for the period 1958 to 2002 demonstrate that this magnitude of temperature change did indeed occur. Fig. 12 explains by temperature alone (related to increase in atmospheric temperature, advection change or water mass location) the change in Calanus dominance that occurred in the North Sea during the regime shift (Reid et al. 2003b). Low temperatures were nearly exclusively observed prior to the shift, while higher temperatures (with the exception of the negative NAO year in 1996) were mainly observed after the shift (Beaugrand 2004b).

Table 2. Tests of comparison of breadth of Calanus finmarchicus (C.fin) and Calanus helgolandicus (C.hel). p $\delta$ : probability of separation of the 2 niches. For description of abundance categories 1 to 4 see 'Materials and methods'

\begin{tabular}{|lcccccccccccc|}
\hline \multirow{2}{*}{ Month } & \multicolumn{3}{c}{ Category 1 $(>0 \%)$} & \multicolumn{3}{c}{ Category 2 $(>25 \%)$} & \multicolumn{4}{c}{ Category $3(>50 \%)$} & \multicolumn{3}{c|}{ Category $4(>75 \%)$} \\
& C.fin & C.hel & p $\delta$ & C.fin & C.hel & p $\delta$ & C.fin & C.hel & p $\delta$ & C.fin & C.hel & p $\delta$ \\
\hline January & 8.15 & 7.36 & $<0.01$ & 8.11 & 7.01 & $<0.01$ & 7.97 & 6.46 & $<0.01$ & 6.88 & 6.64 & $<0.01$ \\
February & 8.46 & 7.37 & $<0.01$ & 8.39 & 7.21 & $<0.01$ & 8.55 & 6.52 & $<0.01$ & 7.14 & 5.94 & $<0.01$ \\
March & 8.84 & 7.55 & $<0.01$ & 8.95 & 7.19 & $<0.01$ & 9.22 & 6.97 & $<0.01$ & 8.97 & 6.57 & $<0.01$ \\
April & 8.68 & 7.87 & $<0.01$ & 8.32 & 7.44 & $<0.01$ & 8.65 & 6.91 & $<0.01$ & 8.55 & 6.66 & $<0.01$ \\
May & 7.95 & 7.38 & $<0.01$ & 7.42 & 6.93 & $<0.01$ & 7.19 & 6.51 & $<0.01$ & 7.46 & 5.92 & $<0.01$ \\
June & 7.34 & 6.36 & $<0.01$ & 7.12 & 6.01 & $<0.01$ & 6.85 & 5.69 & $<0.01$ & 6.82 & 5.26 & $<0.01$ \\
July & 7.49 & 6.37 & $<0.01$ & 7.12 & 5.92 & $<0.01$ & 6.51 & 5.74 & $<0.01$ & 5.83 & 5.17 & $<0.01$ \\
August & 6.97 & 5.85 & $<0.01$ & 6.44 & 5.92 & $<0.01$ & 5.85 & 6.17 & $<0.01$ & 5.14 & 5.93 & $<0.01$ \\
September & 7.30 & 6.32 & $<0.01$ & 6.71 & 6.08 & $<0.01$ & 6.17 & 6.21 & $<0.01$ & 5.47 & 6.05 & $<0.01$ \\
October & 7.75 & 6.75 & $<0.01$ & 7.65 & 6.68 & $<0.01$ & 7.36 & 7.05 & $<0.01$ & 7.61 & 6.66 & $<0.01$ \\
November & 7.82 & 6.56 & $<0.01$ & 8.09 & 6.48 & $<0.01$ & 8.31 & 5.68 & $<0.01$ & 8.45 & 5.19 & $<0.01$ \\
December & 7.74 & 6.55 & $<0.01$ & 7.75 & 6.62 & $<0.01$ & 7.45 & 6.12 & $<0.01$ & 6.42 & 5.52 & $<0.01$ \\
\hline
\end{tabular}


a

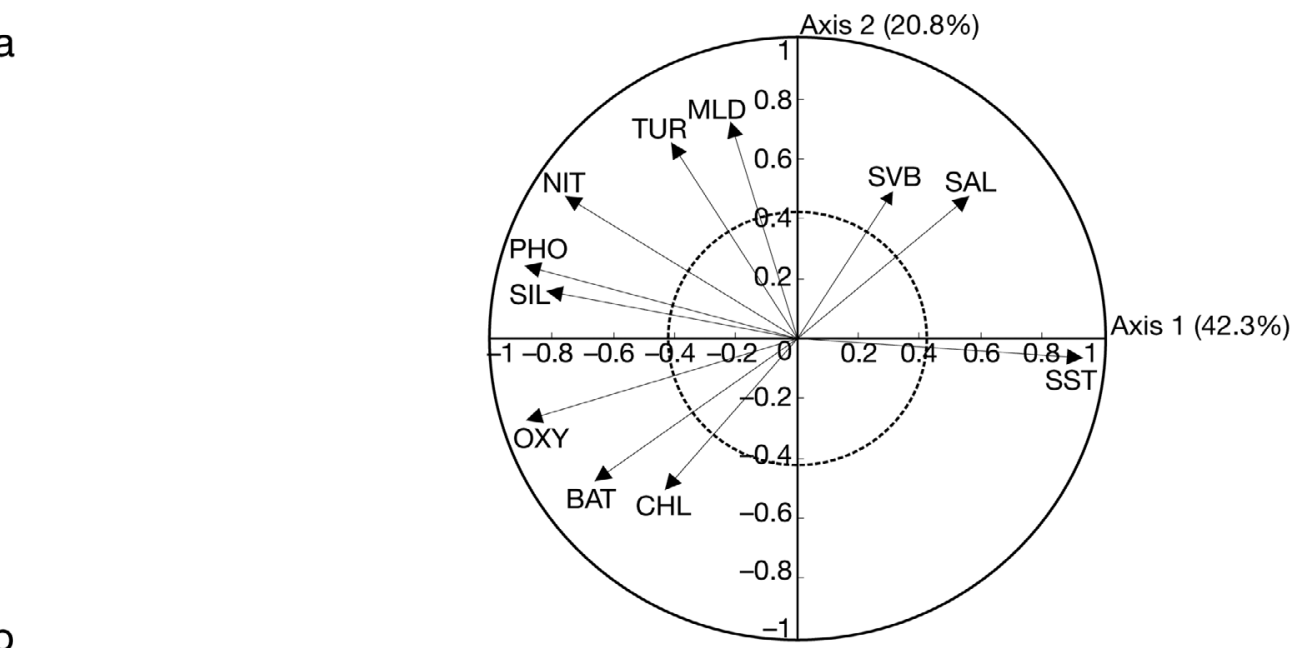

b
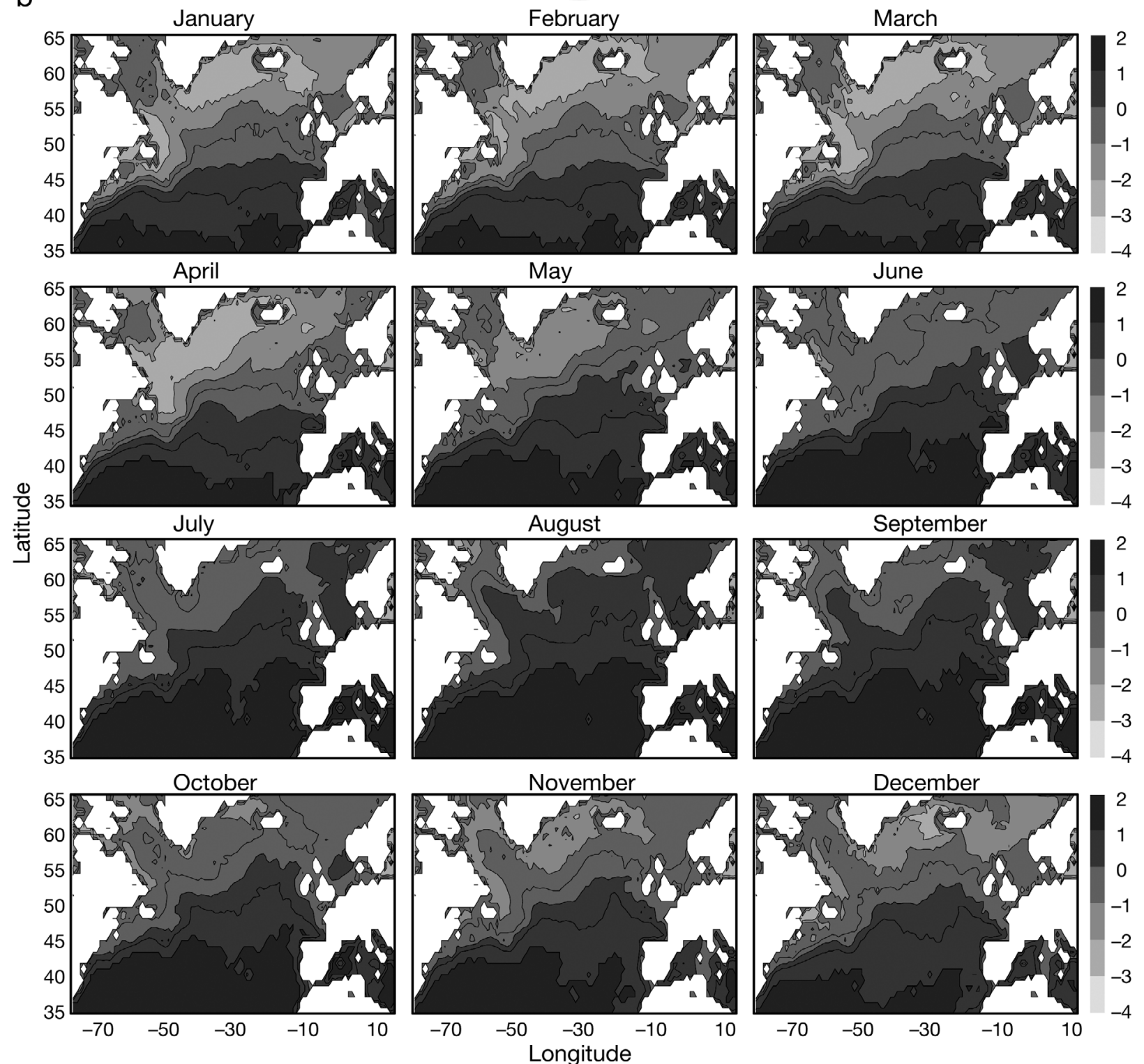

Fig. 8. Standardised principal component analysis of environmental data. (a) Normalised Eigenvectors 1 and 2 (63.1\%); circles of correlation (solid) and of regime descriptor contribution (dashed, C = 0.43) also shown. BAT: bathymetry; CHL: chlorophyll $a$; MLD: mixed-layer depth; NIT: nitrate; OXY: oxygen; PHO: phosphate; SAL: salinity; SIL: silicate; SST: sea surface temperature; SVB: variation in bathymetry; TUR: turbulence rating. (b) Spatial and monthly changes in first principal component (42.3\% of total variance) 
a

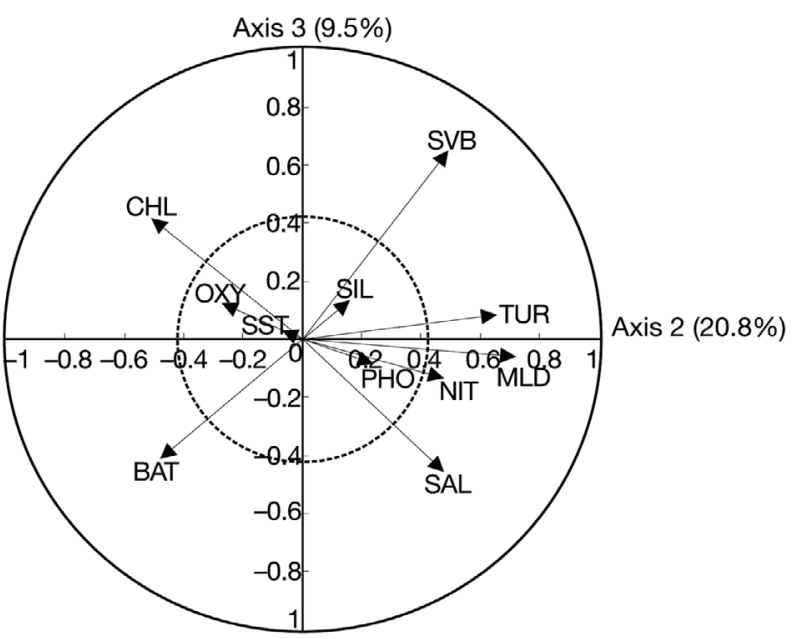

b
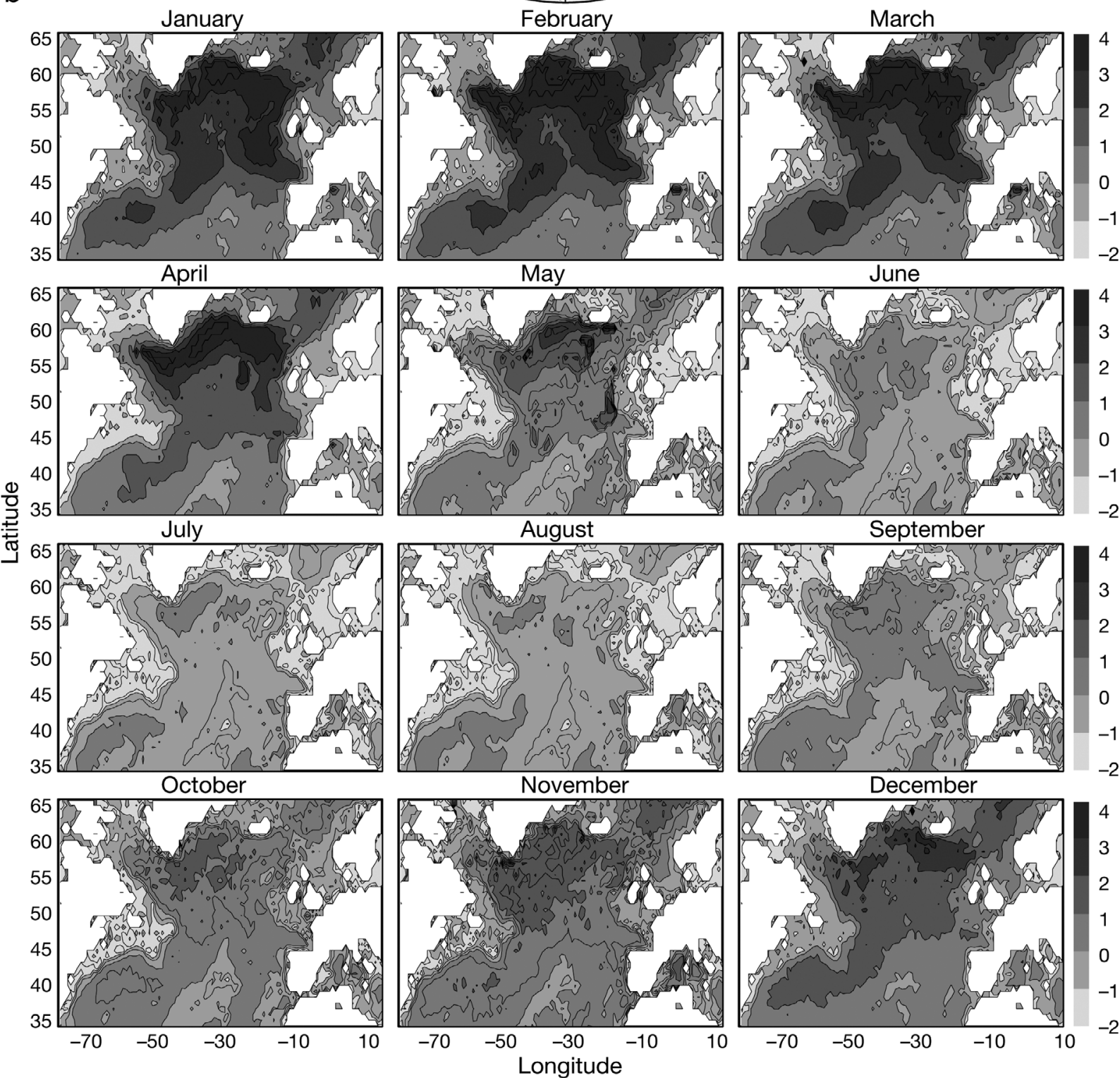

Fig. 9. Standardised principal component analysis of environmental data. (a) Normalised Eigenvectors 2 and 3 (30.3\%); circles of correlation (solid) and of regime descriptor contribution (dashed, C = 0.43) also shown. BAT: bathymetry; CHL: chlorophyll; MLD: mixed-layer depth; NIT: nitrate; PHO: phosphate; SAL: salinity; SIL: silicate; SST: sea surface temperature; SVB: variation in bathymetry; TUR: turbulence rating. (b) Spatial and monthly changes in second principal component (20.8\% of total variance) 
a

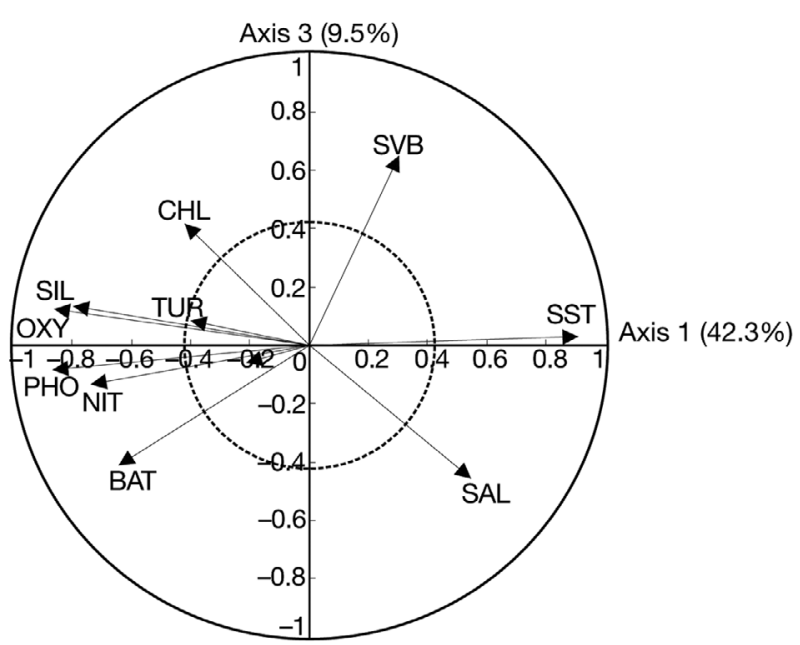

b
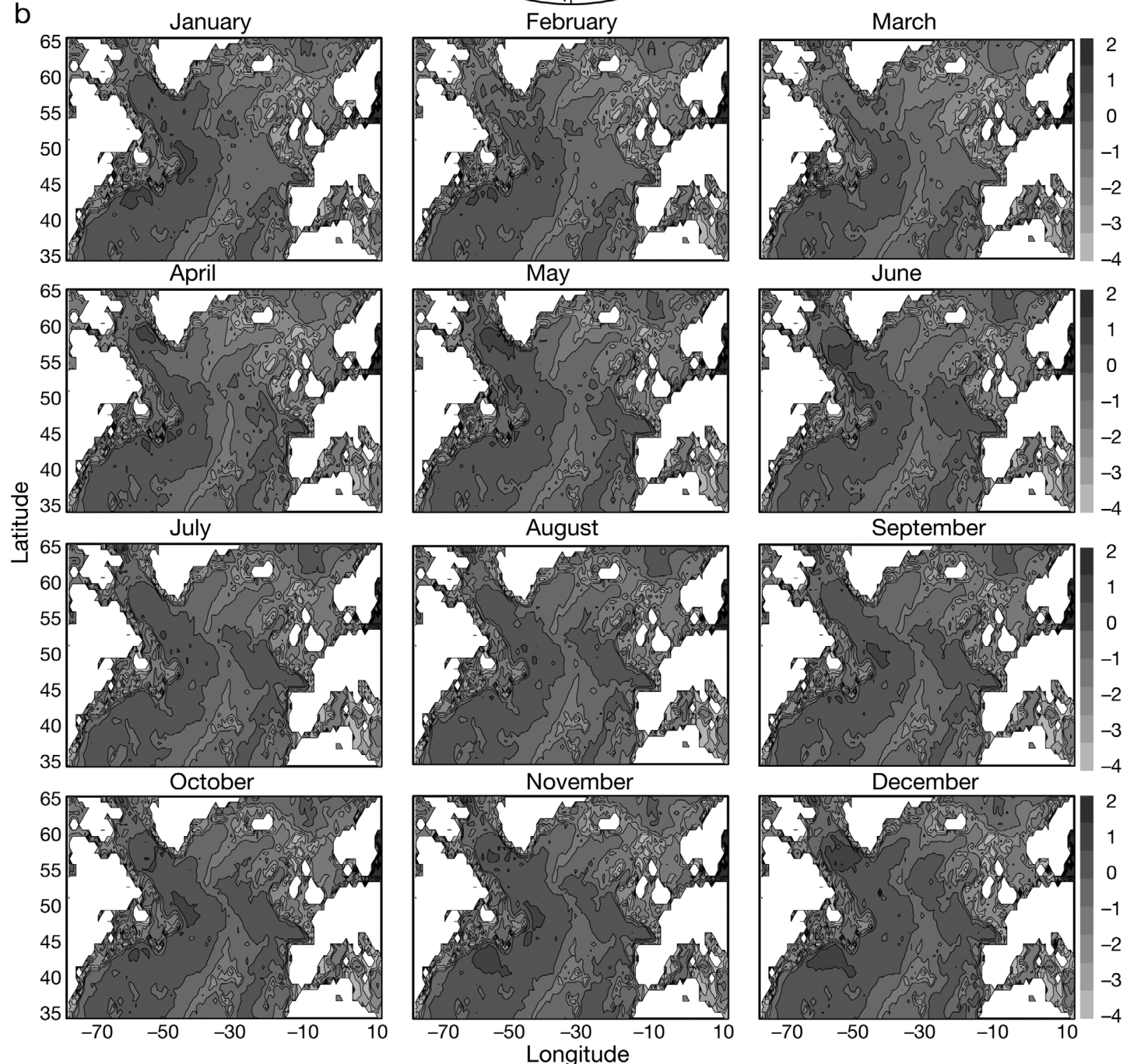

Fig. 10. Standardised principal component analysis of environmental data. (a) Normalised Eigenvectors 1 and 3 (51.8\%); circles of correlation (solid) and of regime descriptor contribution (dashed, C = 0.43) also shown. BAT: bathymetry; CHL: chlorophyll; MLD: mixed-layer depth; NIT: nitrate; PHO: phosphate; SAL: salinity; SIL: silicate; SST: sea surface temperature; SVB: variation of bathymetry; TUR: turbulence rating. (b) Spatial and monthly changes in third principal component (9.5\% of the total variance) 


\section{Calanus finmarchicus}

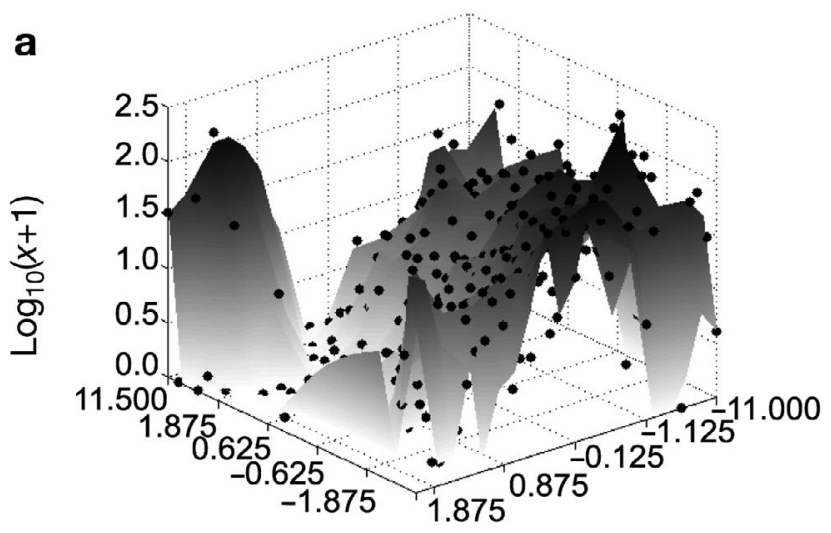

Second component (water column stability)
First component (SST, oxygen, nutrients)

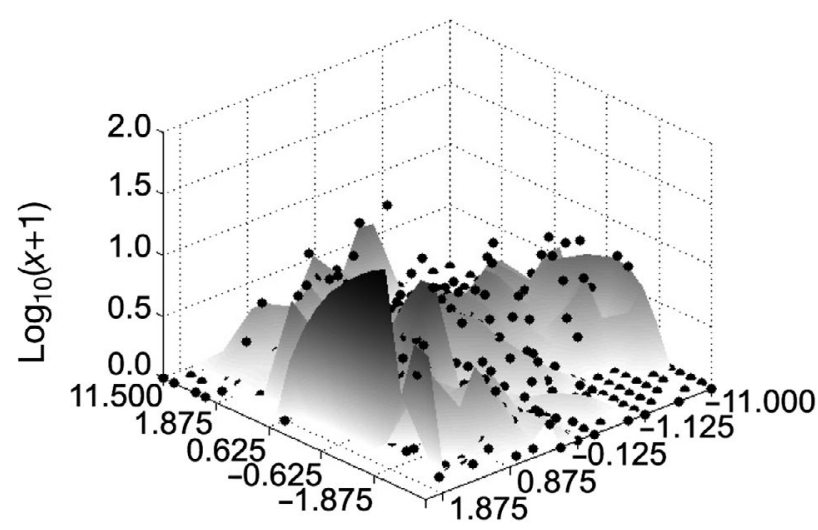

Second component (water column stability)
First component (SST, oxygen, nutrients)

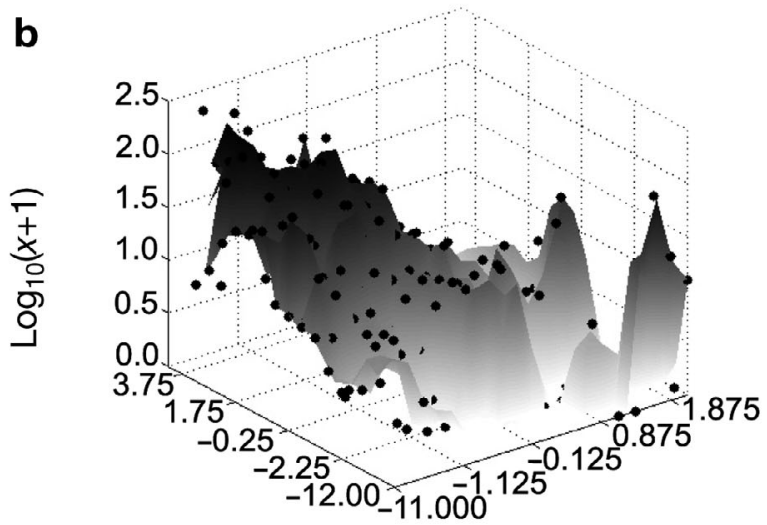

Third component (variation of the bathymetry)
Second component (water column stability)

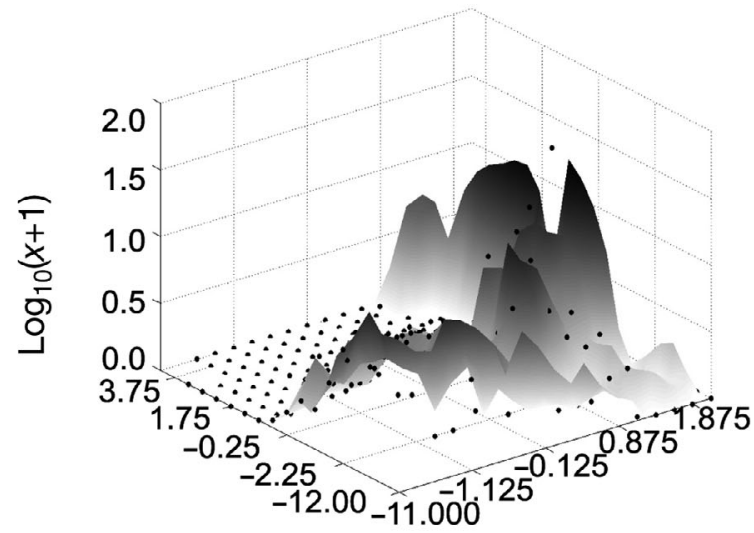

Third component (variation of the bathymetry)
Second component (water column stability)

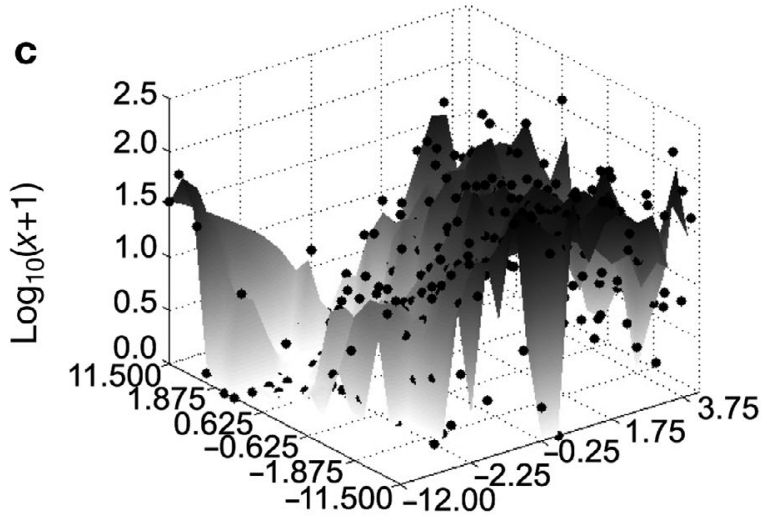

First component (SST, oxygen, nutrients)
Third component (variation of the bathymetry)

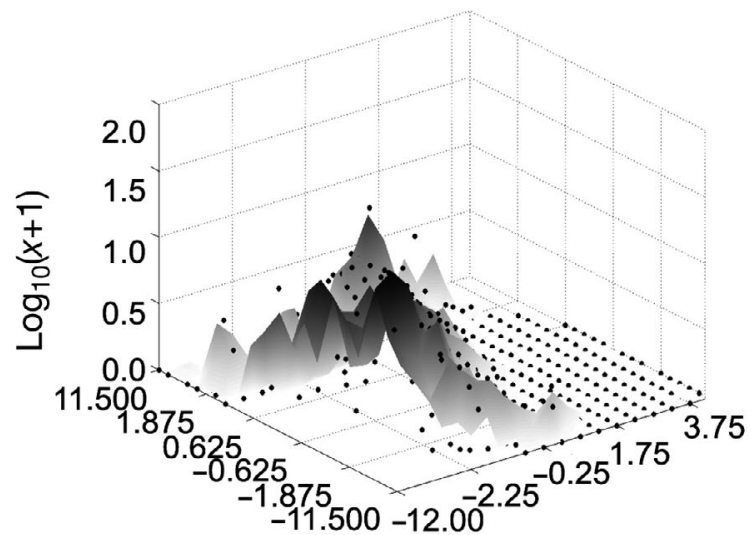

First component

Third component (SST, oxygen, nutrients) (variation of the bathymetry)

Fig. 11. Calanus finmarchicus and C. helgolandicus. Representation of the ecological niche (sensu Hutchinson 1957) using the first 3 principal components, showing abundance (indicated by shading) as a function of (a) first and second principal components (b) second and third principal components and (c) first and third principal components 


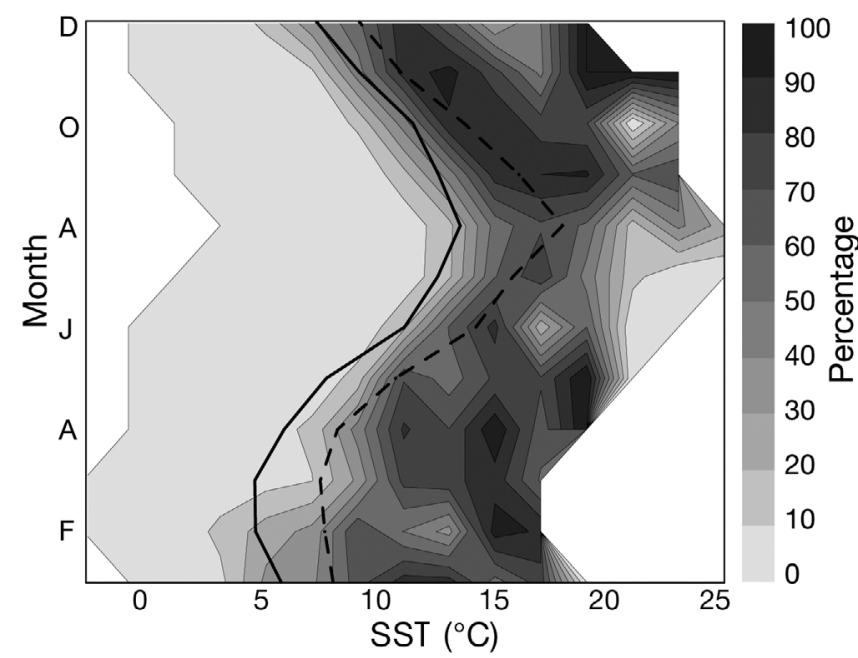

Fig. 12. Calanus helgolandicus. Percentage contribution to total Calanus (C. finmarchicus plus C. helgolandicus); minimum (solid line) and maximum (dashed line) monthly SSTs for North Sea are superimposed

\section{DISCUSSION}

This study has shown that the (Hutchinson's) ecological niche of Calanus finmarchicus and that of C. helgolandicus are significantly separated despite the similar morphology of the species (Fleminger \& Hulsemann 1977, Bucklin et al. 1995). The niche of $C$. helgolandicus is smaller than that of its congener with a few exceptions for higher abundance categories mainly when $C$. helgolandicus has its seasonal maximum in abundance. These exceptions are probably related to the positive relationships between abundance and dispersal in the pelagic realm (Beaugrand et al. 2001). Fig. 16 summarises the different environmental optima of both Calanus species in the present study. The subarctic species $C$. finmarchicus has a broader tolerance interval than its congener and is therefore able to support larger environmental variations (Fig. 16). This species is adapted to a cold oceanic environment, with high mixing during the winter and more nutrients, silicates, oxygen, and is therefore indicative of the Atlantic Arctic Biome and especially

\section{Temporal stability of thermal tolerance range}

Fig. 13 shows that the thermal niche of both calanus species changed regardless the state of the North Atlantic Oscillation $(\mathrm{r}=0.79, \mathrm{p}<0.01, \mathrm{n}=133$ for C. finmarchicus; $\mathrm{r}=0.77, \mathrm{p}<0.01$, $\mathrm{n}=128$ for $C$. helgolandicus). Beaugrand $(2004 \mathrm{~b})$ stressed that the timing of the shift varied according to species, trophic levels and spatial centre of distribution of the individual organisms. However, the use of different time periods did not affect the results, since similar results were obtained for periods before and after the 1980s regime shift (Fig. 14) $(\mathrm{r}=0.88, \mathrm{p}<0.01, \mathrm{n}=$ 135 for C. finmarchicus; $\mathrm{r}=0.92, \mathrm{p}<$ $0.01, \mathrm{n}=135$ for $C$. helgolandicus).

Fig. 15 shows the stability of the thermal niche of the 2 species at the diel scale. No significant change between the thermal niche between daylight and dark periods was identified $(\mathrm{r}=0.76, \mathrm{p}<$ $0.01, \mathrm{n}=142$ for Calanus finmarchicus; $\mathrm{r}=0.94, \mathrm{p}<0.01, \mathrm{n}=142$ for $C$. helgolandicus). This analysis suggests that possible year-to-year changes in the depth distribution of the Calanus species is unlikely to have biased our assessment of Hutchinson's niche for the 2 species.

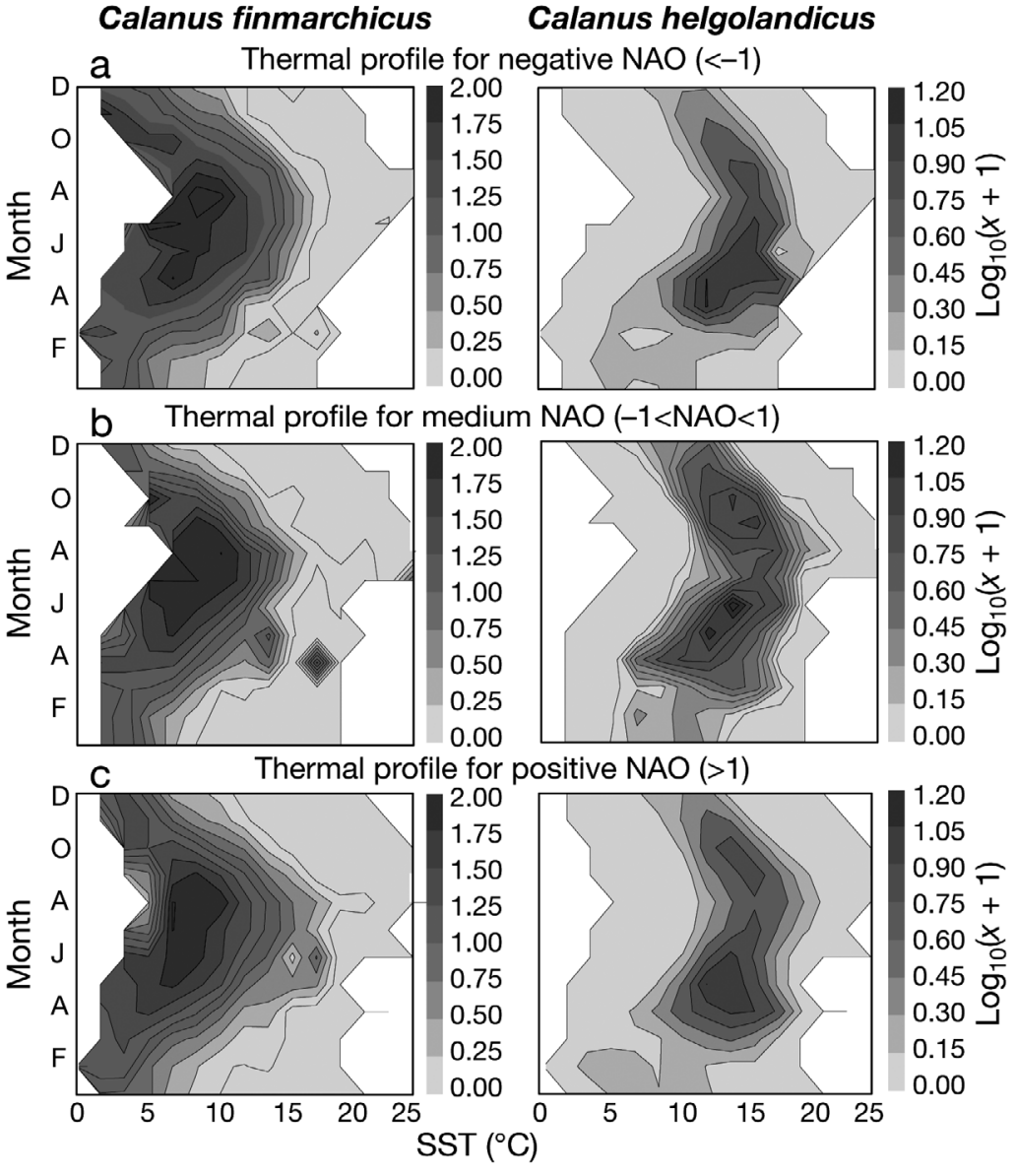

Fig. 13. Calanus finmarchicus and C. helgolandicus. Abundance (decimal logarithm) as a function of state of North Atlantic, using NAO index value of (a) $<-1$, (b) $-1<$ NAO index $<1$, and (c) $>1$ 

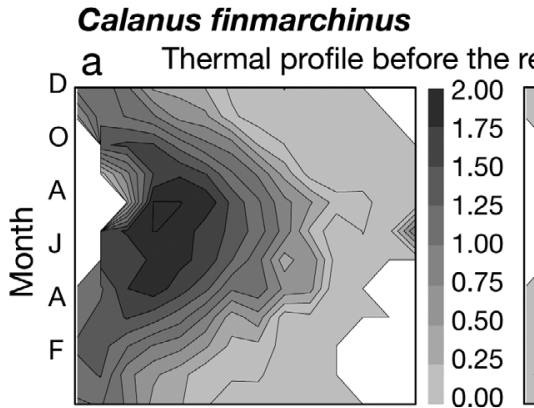

Calanus helgolandicus

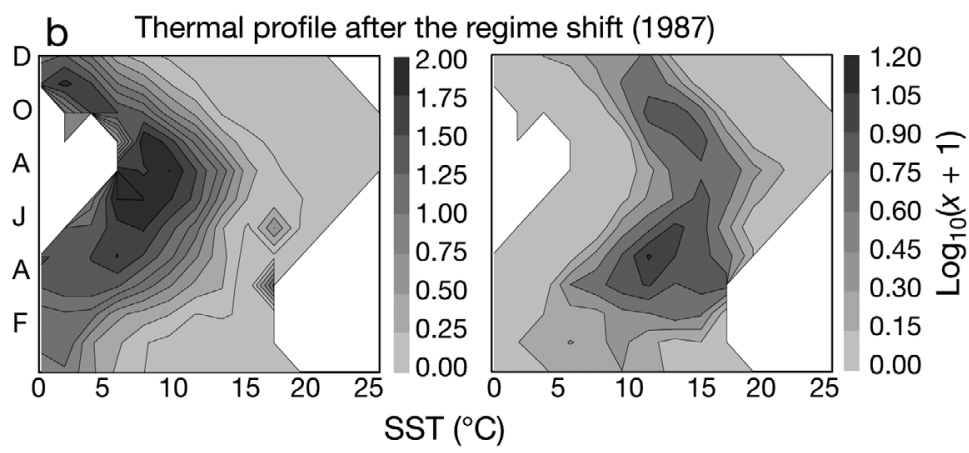

Fig. 14. Calanus finmarchicus and C. helgolandicus. Abundance (decimal logarithm) as a function of state of North Atlantic, for a period (a) before and (b) after 1980s regime shift

\section{Calanus finmarchinus}

\section{Calanus helgolandicus}
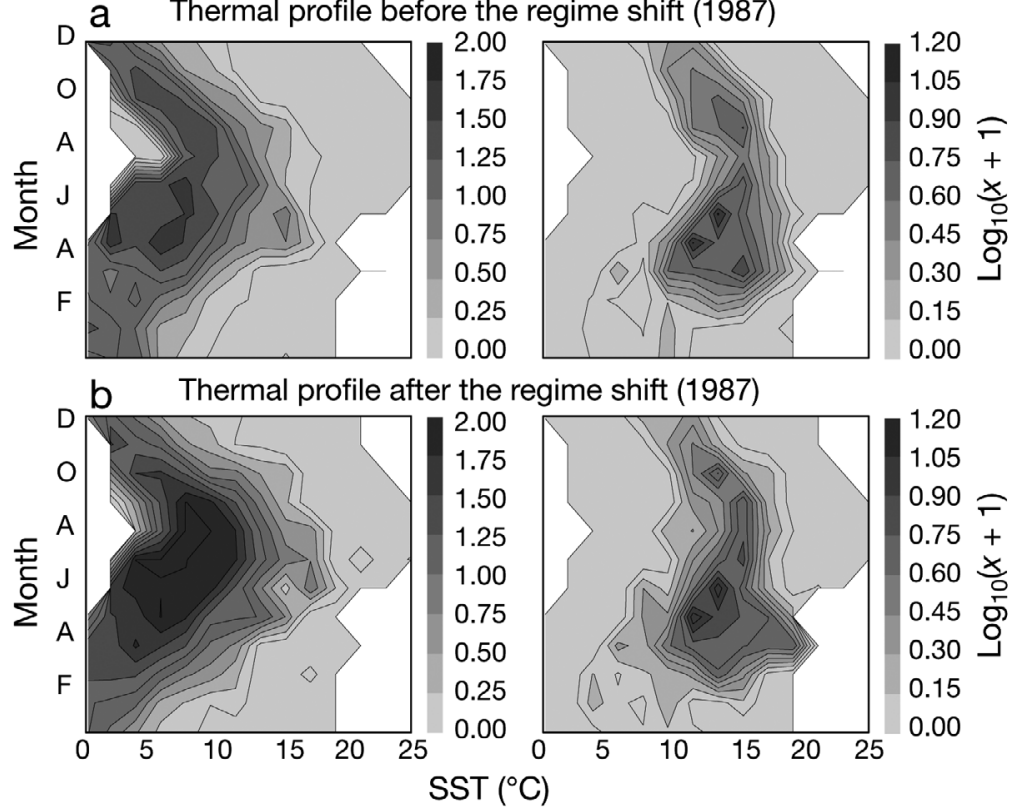

the regime shift (1987)

Fig. 15. Calanus finmarchicus and C. helgolandicus. Abundance (decimal logarithm) as a function of state of North Atlantic, for (a) daylight period $(10: 00$ to $14: 00 \mathrm{~h})$ and $(\mathrm{b})$ dark period (22:00 to $04: 00 \mathrm{~h})$

the Atlantic Arctic and Subarctic provinces defined by Longhurst (1998) (see also present Fig. 1). Its congener C. helgolandicus is more adapted to the temperate waters in the Atlantic Westerly Winds Biome (Longhurst 1998), although it is mainly present along shelf- edges (regions with higher spatial variation in bathymetry). Provinces of this biome have typically higher temperature and lower less of nutrients, silicates and oxygen (Longhurst 1998).

Temperature appears to be the factor that influences most of the spatial distribution of the 2 species. This parameter was highly correlated to the first principal component. A number of authors have highlighted the importance of this parameter for the physiology, the biological cycle and the ecology of copepods (Mauchline 1998, Halsband-Lenk et al. 2002, Lindley \& Reid 2002). Beaugrand et al. (2001) have shown the close link between the spatial distribution in copepod diversity and temperature. Currie (1991) suggested that this parameter was the principal factor explaining the difference in diversity between the equator and the poles. Temperature influences growth, development and reproduction of many plankton species (Halsband-Lenk et al. 2002).

Temperature covaries negatively with nutrients and oxygen concentration so that a change in temperature is accompanied by a change in nutrient and oxygen concentration over the study area. These relationships hold true, because when temperature increases, biological production also increasing, thus consuming nutrients (Russel-Hunter 1970). Furthermore, when temperature increases, stratification is strengthened, limiting nutrient input from deeper waters (Beaugrand et al. 2001). The relationship between temperature and oxygen is related to the physical link between oxygen solubility and temperature (Millero et al. 2002). Therefore, we believe that the main driving mechanism is temperature and not its covariates, although it is possible that nutrients and oxygen also play a role, especially through food web interactions (Legendre \& Rassoulzadegan 1995). Indeed, Legendre \& Rassoulzadegan (1995) showed that by altering nutrient concentration, changes in phytoplankton composition can impact higher trophic levels.

The structure of the water column indicated by the wind-induced turbulence index and mixed-layer depth is also an important factor. It appears that Calanus finmarchicus is mainly located in oceanic regions with lower stratification than C. helgolandicus. The struc- 


\begin{tabular}{|c|c|c|}
\hline Calanus finmarchicus & & Calanus helgolandicus \\
\hline Lower values & Temperature & $\Longrightarrow$ Higher values \\
\hline $6-10.6^{\circ} \mathrm{C}$ & & $11.4-16.1^{\circ} \mathrm{C}$ \\
\hline $\begin{array}{l}\text { Lower values } \\
\text { 33.8-35 }\end{array}$ & Salinity & $\begin{array}{r}\longrightarrow \text { Higher values } \\
35-35.5\end{array}$ \\
\hline $\begin{array}{l}\text { Higher values } \\
6.4-7.3 \mathrm{ml} \mathrm{I}^{-1}\end{array}$ & Oxygen dissolved & $\begin{array}{l}\longrightarrow \text { Lower values } \\
\quad 5.9-6.6 \mathrm{ml} \mathrm{I}^{-1}\end{array}$ \\
\hline Higher values & Phosphate & $\longrightarrow$ Lower values \\
\hline $0.2-0.8 \mu \mathrm{mol} \mathrm{I}^{-1}$ & & $0.1-0.3 \mu \mathrm{mol} \mathrm{I}^{-1}$ \\
\hline $\begin{array}{l}\text { Higher values } \\
1.3-13.9 \mathrm{~mol} \mathrm{I}^{-1}\end{array}$ & Nitrate & $\longrightarrow \begin{array}{c}\text { Lower values } \\
0.1-4.2 \mu \mathrm{mol} \mathrm{I}^{-1}\end{array}$ \\
\hline $\begin{array}{l}\text { Higher values } \\
1.1-6.8 \mu \mathrm{mol} \mathrm{I}^{-1}\end{array}$ & Silicate & 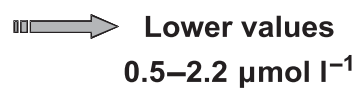 \\
\hline $\begin{array}{l}\text { Higher values } \\
627.8-1482.4 \mathrm{~m}^{3} \mathrm{~s}^{-3}\end{array}$ & $\begin{array}{c}\text { Wind-induced } \\
\text { turbulence }\end{array}$ & $\underset{604.2-1135.9 \mathrm{~m}^{3} \mathrm{~s}^{-3}}{\longrightarrow \text { Lower values }}$ \\
\hline $\begin{array}{l}\text { Higher values } \\
\text { 13.4-185.6 m }\end{array}$ & Mixed-layer depth & $\begin{array}{l}\longrightarrow \text { Lower values } \\
21.1-51.7 \mathrm{~m}\end{array}$ \\
\hline $\begin{array}{l}\text { Higher values } \\
3513-270 \mathrm{~m}\end{array}$ & Bathymetry & $\begin{array}{c}\longrightarrow \text { Lower values } \\
1217-82 \mathrm{~m}\end{array}$ \\
\hline $\begin{array}{l}\text { Higher values } \\
30.1-0.5 \mathrm{~m}\end{array}$ & $\begin{array}{l}\text { Variation of } \\
\text { bathymetry }\end{array}$ & $\begin{array}{c}\text { Lower values } \\
79.5-4.5 \mathrm{~m}\end{array}$ \\
\hline $\begin{array}{l}\text { Values } \\
0.1-2.4 \mathrm{mg} \mathrm{m}^{-3}\end{array}$ & Chlorophyll & 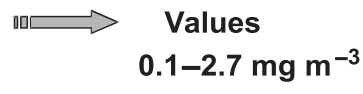 \\
\hline
\end{tabular}

Fig. 16. Calanus finmarchicus and C. helgolandicus. Influence of different abiotic variables on the 2 species. Environmental optima determined using first and ninth decile for each environmental parameter for which the relevant Calanus species was superior to the first quartile. It can be seen that C. helgolandicus is indicative of the Westerly Winds Biome for regions above the shelf edge (e.g. regions with high spatial variability in bathymetry) while C. finmarchicus is indicative of the Arctic biome (especially subarctic and Arctic Atlantic province; Longhurst 1998)

ture of the water column is likely to have a substantial influence on zooplankton distribution, life strategy and population dynamics (Longhurst 1998, Heath et al. 1999). A negative relationship between stratification and zooplankton biomass was reported for the Californian coast by Roemmich \& McGowan (1995). They suggested that a longer stratification period, as well as stronger stratification, might hamper the interchange of nutrients from deeper to surface waters, limiting phytoplankton growth and ultimately food for higher trophic levels.

Bathymetry also influences the spatial distribution of the 2 species, although to a lesser extent than temper- ature. Indeed, Calanus helgolandicus is mainly centred over areas between 0 and $500 \mathrm{~m}$ of depth whereas C. finmarchicus is generally present in deeper areas. These results confirm earlier works that classified C. finmarchicus as primarily an oceanic species and $C$. helgolandicus as a pseudo-oceanic species (Beaugrand et al. 2001, Bonnet et al. 2005, Fleminger \& Hulsemann 1977). Bathymetry is especially important for C. helgolandicus (Beaugrand 2004a, Bonnet et al. 2005). Fleminger \& Hulsemann (1977, their Fig. 5) proposed a map of the spatial distribution of both Calanus studied in this work. Our results are similar, and differences noted for $C$. finmarchicus are mainly related to the use of presence data by Fleminger \& Hulsemann (1977) whereas abundance data were used in the present study. Furthermore, $45 \mathrm{yr}$ of CPR sampling are now available while Fleminger \& Hulsemann (1977) based their synthesis on $17 \mathrm{yr}$.

Identification and quantification of environmental factors involved in the spatial regulation and ecological niche of Calanus finmarchicus and C. helgolandicus may enable the calculation of habitat-suitability maps (Pulliam 2000). The fact that temperature is an important controlling factor of the spatial distribution of $C$. finmarchicus and C. helgolandicus has significant implications in the context of global climate change. Indeed, temperature is one of the parameters which will be the most affected (IPCC 2001). Moreover, temperature is the most accessible parameter in the various scenarios suggested by the IPCC (2001). This makes possible the realisation of scenarios of changes in the spatial distribution of $C$. finmarchicus and $C$. helgolandicus. Forecasting the distribution of $C$. finmarchicus and $C$. helgolandicus with Ocean General Circulation Models (OGCMs) outputs is of great interest because these Calanus species are key structural species of pelagic ecosystems in the North Atlantic and adjacent seas. They have a significant role in the life cycle of many exploited fishes. For example, Beaugrand et al. (2003) recently showed the importance of $C$. finmarchicus for the survival of larval cod in the North Sea. A positive correlation between cod recruitment and the abundance of $C$. finmarchicus was detected. The relation was reversed with $C$. helgolandicus. Mechanisms pro- 
posed were based on the 'match/mismatch' hypothesis (Cushing 1996). C. finmarchicus was abundant in the North Sea prior to the 1980s regime shift. As this species has its seasonal maximum in spring, it ensured a great availability of prey for cod larvae (period of occurrence from March to August). C. finmarchicus decreased during the 1980 s while its congener increased. This change in dominance reduced the availability of Calanus prey in spring because C. helgolandicus has its seasonal maximum in autumn at a time when cod larvae feed on larger prey such as euphausiids or other fishes.

A remarkable feature of our study is that the environmental optimum of Calanus species varies seasonally for all abiotic parameters. Theses seasonal fluctuations might be influenced by the spatial variability in the seasonality of both species (Planque et al. 1997). For C. finmarchicus, seasonal fluctuations could be related to large-scale differences in the timing of ontogenetic vertical migration. Another hypothesis is that they could be related to the differential sensitivity of the mean developmental stages of Calanus population to temperature that has been observed in some experiments (Harris et al. 2000).

The use of this ecological niche approach has allowed an explanation of the shift in Calanus dominance to be outlined. Reid et al. (2003b) showed a substantial and sustained reduction in the percentage contribution of $C$. finmarchicus to total Calanus in the North Sea. While in 1962, C. finmarchicus comprised $80 \%$ of Calanus spp. in the North Sea, C. helgolandicus comprised $80 \%$ of Calanus identified by the CPR survey in 2000. As seen in Fig. 12, Calanus dominance in the North Sea is highly sensitive to temperature, especially in spring and summer. We have demonstrated that the shift in dominance could have been triggered solely by temperature changes in the North Sea. Sea surface temperature changes are likely to be related to changes in air temperature (Beaugrand 2004b) over the region and changes in advection recently discussed in Reid et al. (2003b). Reid et al. (2003b) reported that when the NAO was positive, the strength of the European shelf-edge current, which flows northwards, increased and that oceanic inflow into the northern part of the North Sea was strengthened. During the cold regime in the North Sea prior to 1980, this region was at the boundary between a subarctic biome and a more temperate biome (Longhurst 1998). As C. finmarchicus is indicative of the Atlantic Arctic biome, the change in the proportion of Calanus in the North Sea may indicate that the subarctic biome has moved northwards. This has been recently suggested by Beaugrand (2004b). A northward movement of plankton has been detected using calanoid copepods in the northeastern part of the North Atlantic
(Beaugrand et al. 2002) and a similar shift has been found for fish (Perry et al. 2005).

This study has shown the usefulness of Hutchinson's ecological niche concept, wich in general has been poorly utilised by ecologists. However, it is important to note that in the present study we assessed the realised, not the fundamental, niche of Calanus spp. Hutchinson (1957) made this distinction and stated that the realised niche should always be smaller than the fundamental niche as species interactions eliminate individuals from favourable biotopes. However, Pulliam (2000) recently showed that when dispersal is high, the realised niche can be larger than the fundamental niche. This is probably the case here as the oceanic pelagic realm is continuous, 3-dimensional and without geographical barriers that make biogeographical regions less well-defined than in the terrestrial realm. One way to assess the fundamental niche would be to base the assessment of the species niche on a physiological model such as that described by Pulliam (2000).

Acknowledgements. We are grateful to all past and present members and supporters of the Sir Alister Hardy Foundation for Ocean Science, whose continuous efforts have allowed the establishment and maintenance of the long-term CPR data set. The survey depends on the owners, masters, and crews of the ships that tow the CPRs. The research was supported by the UK's Department for Environment, Food and Rural Affairs (DEFRA) and the European Network of Excellence EUROCEANS. This work was also supported by the French programme ZOOPNEC (Programme National d'Écologie Côtière centré sur le Zooplancton).

\section{LITERATURE CITED}

Batten SD, Clark R, Flinkman J, Hays G and 6 others (2003) CPR sampling: the technical background, materials, and methods, consistency and comparability. Prog Oceanogr 58:193-215

Beaugrand G (2003) Long-term changes in copepod abundance and diversity in the north-east Atlantic in relation to fluctuations in the hydro-climatic environment. Fish Oceanogr 12:270-283

Beaugrand G (2004a) Continuous plankton records: plankton atlas of the North Atlantic Ocean (1958-1999). I. Introduction and methodology. Mar Ecol Prog Ser Suppl 2004:3-10

Beaugrand G (2004b) The North Sea regime shift: evidence, causes, mechanisms and consequences. Prog Oceanogr 60:245-262

Beaugrand G, Ibañez F, Lindley JA (2001) Geographical distribution and seasonal and diel changes of the diversity of calanoid copepods in the North Atlantic and North Sea. Mar Ecol Prog Ser 219:205-219

Beaugrand G, Reid PC, Ibañez F, Lindley JA, Edwards M (2002) Reorganisation of North Atlantic marine copepod biodiversity and climate. Science 296:1692-1694

Beaugrand G, Brander KM, Lindley JA, Souissi S, Reid PC (2003) Plankton effect on cod recruitment in the North Sea. Nature 426:661-664

Bonnet D, Ridchardson A, Harris R, Hirst A and 19 others (2005) An overview of Calanus helgolandicus ecology in European waters. Prog Oceanogr 65:1-53 
Bouvier A (1977) Programme ACPM. Analyse des composantes principales avec des donnees manquantes. Document 77/17, CNRA, Laboratoire de Biometrie, Jouy en Josas

Bucklin A, Frost BW, Kocher TD (1995) Molecular systematics of six Calanus and three Metridia species (Calanoida: Copepoda). Mar Biol 121:655-664

Carlotti F, Krause M, Radach G (1993) Growth and development of Calanus finmarchicus related to the influence of temperature: experimental results and conceptual model. Limnol Oceanogr 38:1125-1134

Currie DJ (1991) Energy and large-scale patterns of animaland plant- species richness. Am Nat 137:27-49

Cushing DH (1996) Towards a science of recruitment in fish populations. In: Kinne O (ed) Excellence in ecology, Book 7. International Ecology Institute, Oldendorf/Luhe

Daro MH (1985) Feeding rhythms and vertical distribution of marine copepods. Bull Mar Sci 37:487-497

Dietrich G (1964) Oceanic polar front survey. Res Geophys 2: 291-308

Ducklow HW, Harris RP (1993) Introduction to the JGOFS North Atlantic Bloom Experiment. Deep-Sea Res II 40:1-8

Fleminger A, Hulsemann K (1977) Geographical range of taxonomic divergence in North Atlantic Calanus (C. helgolandicus, C. finmarchicus and C. glacialis). Mar Biol 40: 233-248

Frontier S, Pichot-Viale D, Leprêtre A, Davoult D, Luczak C (2004) Ecosystèmes: structure, fonctionnement et évolution. Dunod, Paris

Gause GF (1934) The struggle for existence. Williams \& Wilkins, Baltimore, MD

Guisan A, Wilfried T (2005) Predicting species distribution: offering more than simple habitat models. Ecol Lett 8: 993-1009

Hall CJ, Burns CW (2002) Effects of temperature and salinity on the survival and egg production of Gladioferens pectinatus Brady (Copepoda: Calanoida). Estuar Coast Shelf Sci 55:557-564

Halsband-Lenk C, Hirche HJ, Carlotti F (2002) Temperature impact on reproduction and development of congener copepod populations. J Exp Mar Biol Ecol 271:121-153

Harris RP, Irigoien X, Head RN, Rey C and 5 others (2000) Feeding, growth, and reproduction in the genus Calanus. ICES J Mar Sci 57:1708-1726

Heath MR, Backhaus JO, Richardson K, McKenzie E and 11 others (1999) Climate fluctuations and the spring invasion of the North Sea by Calanus finmarchicus. Fish Oceanogr 8 (Suppl 1):163-176

Hirst AG, Batten SD (1998) Long-term changes in the diel vertical migration behaviour of Calanus finmarchicus in the North Sea are unrelated to fish predation. Mar Ecol Prog Ser 171:307-310

Hutchinson GE (1957) A treatise on limnology: geography, physics, and chemistry 1 . John Wiley \& Sons, London

IPCC (Intergovernmental Panel on Climate Change) (2001) Climate change 2001: the scientific basis. Cambridge University Press, Cambridge

Jolliffe IT (1986) Principal component analysis. SpringerVerlag, New York

Kleppel GS (1993) On the diets of calanoid copepods. Mar Ecol Prog Ser 99:183-195

Editorial responsibility: Otto Kinne (Editor-in-Chief), Oldendorf/Luhe, Germany
Krauss W (1986) The North Atlantic current. J Geophys Res 91:5061-5074

Legendre P, Legendre L (1998) Numerical ecology. Elsevier Science BV, Amsterdam

Legendre L, Rassoulzadegan F (1995) Plankton and nutrient dynamics in marine waters. Ophelia 41:153-172

Lindley JA, Reid PC (2002) Variations in the abundance of Centropages typicus and Calanus helgolandicus in the North Sea: deviations from close relationships with temperature. Mar Biol 141:153-165

Longhurst A (1998) Ecological geography of the sea. Academic Press, London

Mauchline J (1998) The biology of calanoid copepods. Academic Press, San Diego, CA

Millero FJ, Huang F, Laferiere AL (2002) Solubility of oxygen in the major sea salts as a function of concentration and temperature. Mar Chem 78:217-230

Orlova EL, Boitsov VD, Dolgov AV, Rudneva GB, Nesterova VN (2005) The relationship between plankton, capelin, and cod under different temperature conditions. ICES J Mar Sci 62:1281-1292

Perry AL, Low PJ, Ellis JR, Reynolds JD (2005) Climate change and distribution shifts in marine fishes. Science 308:1912-1915

Planque B, Fromentin JM (1996) Calanus and environment in the eastern North Atlantic. I. Spatial and temporal patterns of C. finmarchicus and C. helgolandicus. Mar Ecol Prog Ser 134:111-118

Planque B, Hays GC, Ibañez F, Gamble JC (1997) Large scale spatial variations in the seasonal abundance of Calanus finmarchicus. Deep-Sea Res I 44:315-326

Pulliam HR (2000) On the relationship between niche and distribution. Ecol Lett 3:349-361

Reid P, Edwards M (2001) Plankton and climate. In: Steele J (ed) Encyclopaedia of sciences. Academic Press, Oxford, p 2194-2200

Reid PC, Colebrook JM, Matthews JBL, Aiken J and 25 others (2003a) The continuous plankton recorder: concepts and history, from plankton indicator to undulating recorders. Prog Oceanogr 58:117-173

Reid PC, Edwards M, Beaugrand G, Skogen M, Stevens D (2003b) Periodic changes in the zooplankton of the North Sea during the twentieth century linked to oceanic inflow. Fish Oceanogr 12:260-269

Roemmich D, McGowan J (1995) Climatic warming and the decline of zooplankton in the California current. Science 267:1324-1326

Russel-Hunter WD (1970) Aquatic productivity. An introduction to some basic aspects of biological oceanography and limnology. Collier-Macmillan, London

Skreslet S, Borja A, Bugliaro L, Hansen G, Meerkotter R, Olsen K, Verdebout J (2005) Some effects of ultraviolet radiation and climate on the reproduction of Calanus finmarchicus (Copepoda) and year class formation in Arcto-Norwegian cod (Gadus morhua). ICES J Mar Sci 62:1293-1300

Sundby S (2000) Recruitment of Atlantic cod stocks in relation to temperature and advection of copepod populations. Sarsia 85:277-298

Woodruff S, Slutz R, Jenne R, Steurer P (1987) A comprehensive ocean-atmosphere dataset. Bull Am Meteorol Soc 68: $1239-1250$

Submitted: April 25, 2006; Accepted: October 20, 2006

Proofs received from author(s): July 6, 2007 